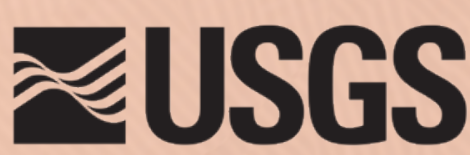

science for a changing world

Prepared in cooperation with the U.S. Air Force Civil Engineering Center, Wright-Patterson Air Force Base

\title{
Update of the Groundwater Flow Model for the Great Miami Buried-Valley Aquifer in the Vicinity of Wright-Patterson Air Force Base near Dayton, Ohio
}

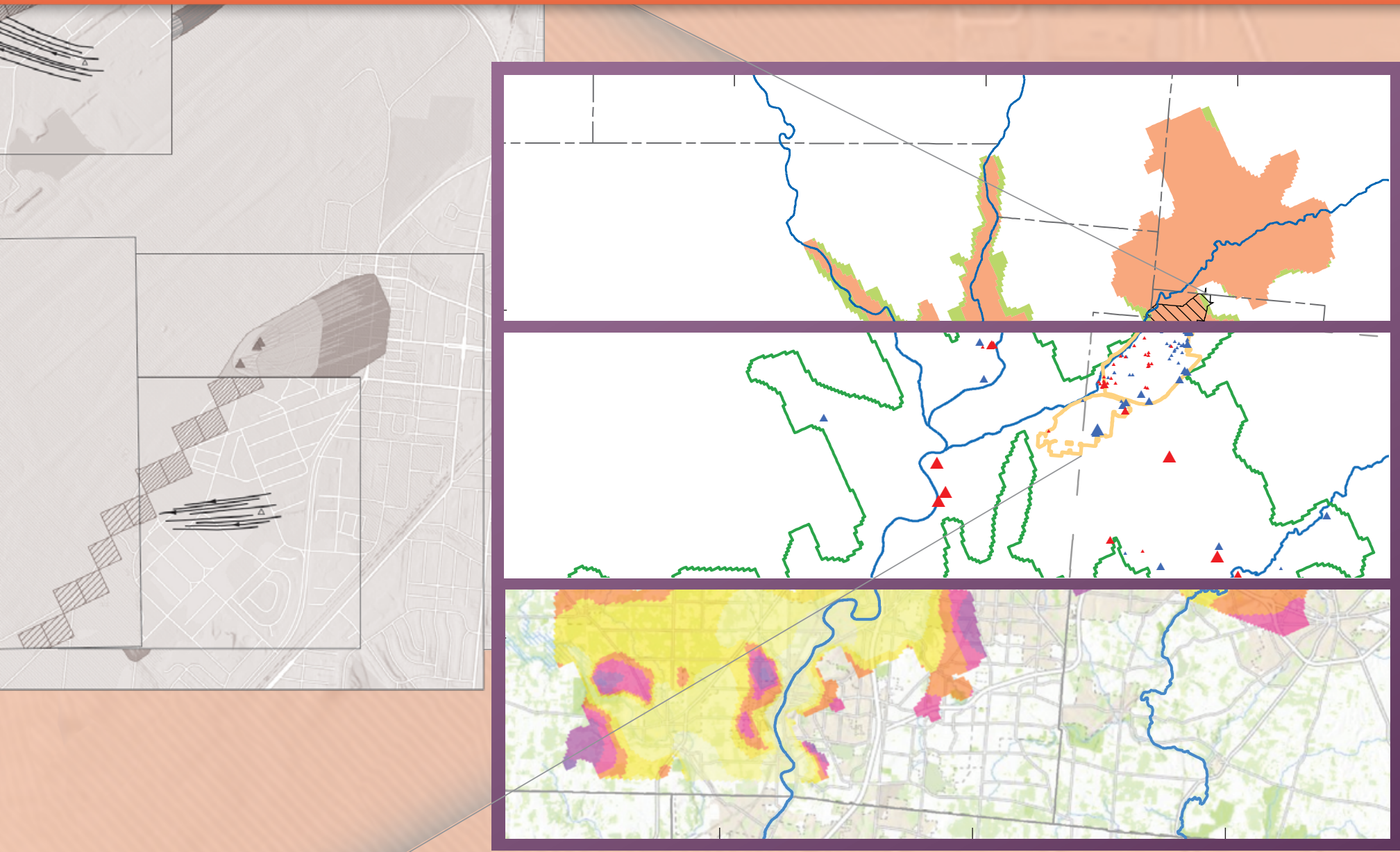

Scientific Investigations Report 2021-5115

U.S. Department of the Interior

U.S. Geological Survey 


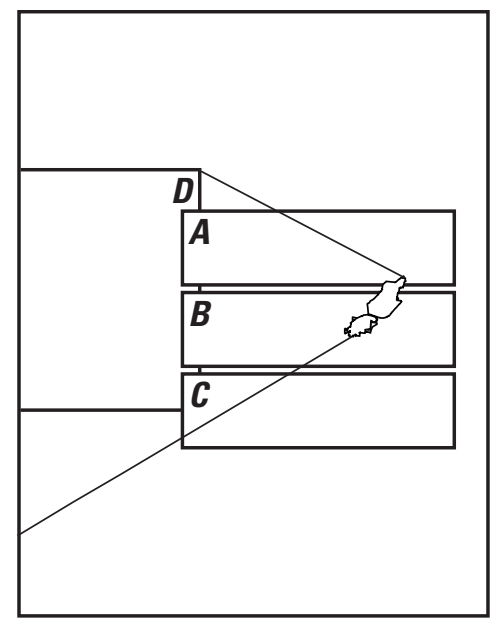

Front cover. $A$, figure 3 of this report; $B$, figure 1 of this report; $C$, figure 9 of this report; $D$, spatial splice of figures 10 through 18 of this report. 


\section{Update of the Groundwater Flow Model for the Great Miami Buried-Valley Aquifer in the Vicinity of Wright-Patterson Air Force Base near Dayton, Ohio}

By Alexander D. Riddle

Prepared in cooperation with the U.S. Air Force Civil Engineering Center,

Wright-Patterson Air Force Base

Scientific Investigations Report 2021-5115 


\section{U.S. Geological Survey, Reston, Virginia: 2021}

For more information on the USGS - the Federal source for science about the Earth, its natural and living resources, natural hazards, and the environment—visit https://www.usgs.gov or call 1-888-ASK-USGS.

For an overview of USGS information products, including maps, imagery, and publications, visit https://store.usgs.gov/.

Any use of trade, firm, or product names is for descriptive purposes only and does not imply endorsement by the U.S. Government.

Although this information product, for the most part, is in the public domain, it also may contain copyrighted materials as noted in the text. Permission to reproduce copyrighted items must be secured from the copyright owner.

Suggested citation:

Riddle, A.D., 2021, Update of the groundwater flow model for the Great Miami buried-valley aquifer in the vicinity of Wright-Patterson Air Force Base near Dayton, Ohio: U.S. Geological Survey Scientific Investigations Report 2021-5115, 36 p., https://doi.org/10.3133/sir20215115.

Data release associated with this report:

Riddle, A.D., 2021, MODFLOW 6 and MODPATH 7 model data sets used for the update of the groundwater flow model for the Great Miami buried-valley aquifer in the vicinity of Wright-Patterson Air Force Base near Dayton, Ohio: U.S. Geological Survey data release, https://doi.org/10.5066/P9FN1JK4.

ISSN 2328-0328 (online) 


\section{Acknowledgments}

The author thanks personnel at Wright-Patterson Air Force Base, particularly Catherine Bartell, for their efforts to collect data that were invaluable for this study.

Several personnel at the U.S. Geological Survey assisted with the modeling, data interpretation, and report development. Dave Lampe provided guidance and insight throughout the entire process. Neal Mathes created maps and interpreted surface-water data. Randy Bayless collected streamflow data for gain/loss studies. Rod Sheets and Christian Langevin provided modeling support. Dave Lampe, Shawn Naylor, Wesley Zell, Rob Darner, and Randy Bayless all provided insightful edits and comments for this report. 



\section{Contents}

Acknowledgments ……...................................................................................................................

Abstract

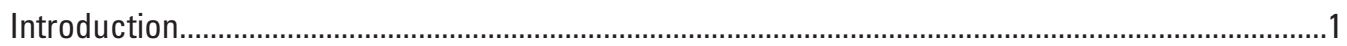

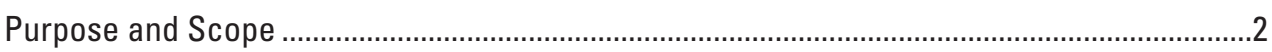

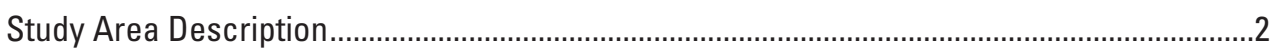

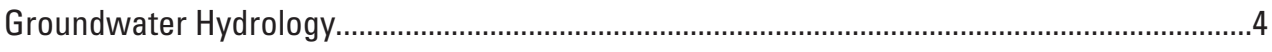

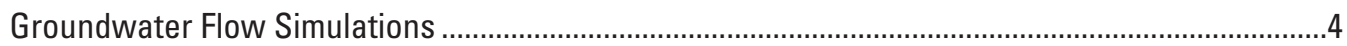

Description of the Original Model .........................................................................................

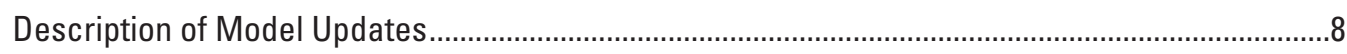

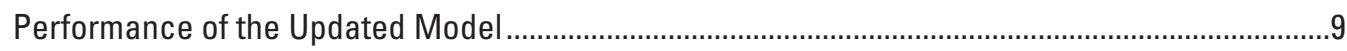

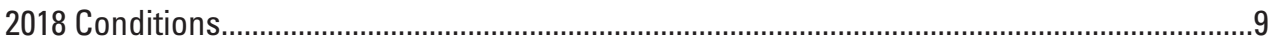

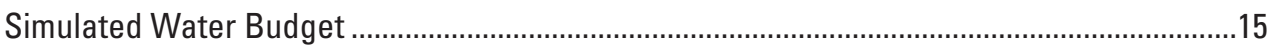

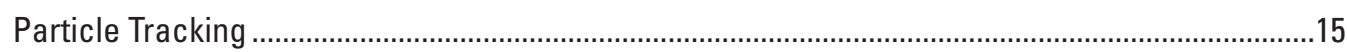

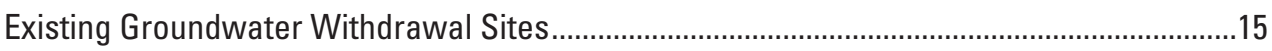

Proposed Groundwater Withdrawal Sites .......................................................................17

Simulated Release Areas ..................................................................................................

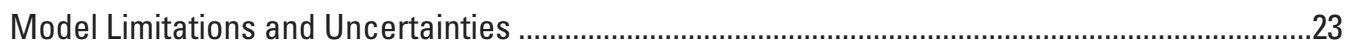

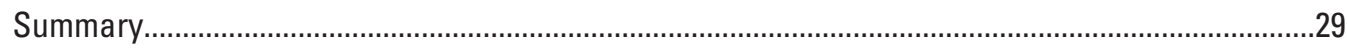

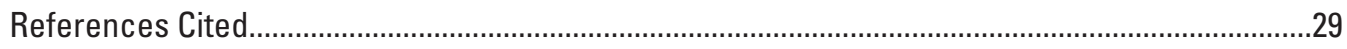

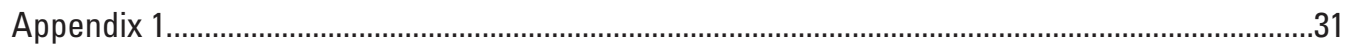

\section{Figures}

1. Map showing overview map of the study area, showing the location of the Wright-Patterson Air Force Base within the model grid ................................................

2. Schematic showing cross section of the groundwater flow model, Wright-Patterson Air Force Base, Ohio ....

3. Map showing the location of the parameter estimation zones for the original model and the updated model.

4. Graph showing the composite scaled sensitivity of groundwater flow model parameters..

5. Figure showing difference between observed water levels and simulated water levels for the entire model domain.

6. Figure showing difference between observed water-level altitudes and simulated water-level altitudes near the Wright-Patterson Air Force Base.

7. Graph showing relation between simulated and measured hydraulic heads for the updated model simulating, A, 1997-2001 conditions, and, B, October 2018 conditions

8. Figure showing location of stream reaches shown as model cells where streamflow gain/loss was determined from measurements made during August 2019.

9. Figure showing simulated altitude of potentiometric surface of the Great Miami buried-valley aquifer, calibrated to October 2018. 
10. Figure showing 1-,5-, and 10-year contributing groundwater areas for groundwater withdrawal sites in Area A, Wright-Patterson Air Force Base...

11. Figure showing 1-, 5-, and 10 -year contributing groundwater areas for groundwater withdrawal sites in Area A and Area B, Wright-Patterson Air Force Base.

12. Figure showing 1-, 5-, and 10-year contributing groundwater areas for proposed groundwater withdrawal sites in Area A, Wright-Patterson Air Force Base.

13. Figure showing 1-, 5-, and 10-year contributing groundwater areas for proposed groundwater withdrawal sites in Area A and Area B, Wright-Patterson Air Force Base

14. Figure showing particle pathlines for a simulated groundwater release at Hangar 4020, Wright-Patterson Air Force Base

15. Figure showing particle pathlines for a simulated groundwater release at Building 60, Wright-Patterson Air Force Base.

16. Figure showing particle pathlines for a simulated groundwater release at Buildings 478/479, Wright-Patterson Air Force Base

17. Figure showing particle pathlines for a simulated groundwater release at WPAFB Fire Training Area and Hazmat Pad 3, Wright-Patterson Air Force Base

18. Figure showing particle pathlines for a simulated groundwater release at Trey Landfill, City of Dayton Fire Training Center, and Outfall 1, Wright-Patterson Air Force Base

\section{Tables}

1. Comparison of root-mean-squared error and mean-absolute difference of measured and simulated hydraulic heads, and between the original groundwater flow model and the updated model

2. Parameters used in construction of the updated groundwater flow model calibrated to October 2018

3. Comparison of measured and simulated streamflow gain or loss for the updated model, Great Miami buried-valley aquifer .

4. Volumetric water budget comparison for original model and the updated model..........17

5. Calculated average travel time to discharge for eight simulated release areas, Wright-Patterson Air Force Base 


\section{Conversion Factors}

U.S. customary units to International System of Units

\begin{tabular}{|c|c|c|}
\hline Multiply & By & To obtain \\
\hline \multicolumn{3}{|c|}{ Length } \\
\hline inch (in.) & 2.54 & centimeter $(\mathrm{cm})$ \\
\hline inch (in.) & 25.4 & millimeter $(\mathrm{mm})$ \\
\hline foot $(\mathrm{ft})$ & 0.3048 & meter $(\mathrm{m})$ \\
\hline mile (mi) & 1.609 & kilometer (km) \\
\hline \multicolumn{3}{|c|}{ Area } \\
\hline square foot $\left(\mathrm{ft}^{2}\right)$ & 0.09290 & square meter $\left(\mathrm{m}^{2}\right)$ \\
\hline square mile $\left(\mathrm{mi}^{2}\right)$ & 2.590 & square kilometer $\left(\mathrm{km}^{2}\right)$ \\
\hline \multicolumn{3}{|c|}{ Volume } \\
\hline gallon (gal) & 0.003785 & cubic meter $\left(\mathrm{m}^{3}\right)$ \\
\hline million gallons (Mgal) & 3,785 & cubic meter $\left(\mathrm{m}^{3}\right)$ \\
\hline cubic foot $\left(\mathrm{ft}^{3}\right)$ & 0.02832 & cubic meter $\left(\mathrm{m}^{3}\right)$ \\
\hline \multicolumn{3}{|c|}{ Flow rate } \\
\hline cubic foot per second $\left(\mathrm{ft}^{3} / \mathrm{s}\right)$ & 0.02832 & cubic meter per second $\left(\mathrm{m}^{3} / \mathrm{s}\right)$ \\
\hline cubic foot per day $\left(\mathrm{ft}^{3} / \mathrm{d}\right)$ & 0.02832 & cubic meter per day $\left(\mathrm{m}^{3} / \mathrm{d}\right)$ \\
\hline gallon per minute (gal/min) & 0.06309 & liter per second $(\mathrm{L} / \mathrm{s})$ \\
\hline gallon per day (gal/d) & 0.003785 & cubic meter per day $\left(\mathrm{m}^{3} / \mathrm{d}\right)$ \\
\hline million gallons per day (Mgal/d) & 0.04381 & cubic meter per second $\left(\mathrm{m}^{3} / \mathrm{s}\right)$ \\
\hline inch per hour (in/h) & 0.0254 & meter per hour $(\mathrm{m} / \mathrm{h})$ \\
\hline inch per year (in/yr) & 25.4 & millimeter per year (mm/yr) \\
\hline \multicolumn{3}{|c|}{ Hydraulic conductivity } \\
\hline foot per day $(\mathrm{ft} / \mathrm{d})$ & 0.3048 & meter per day $(\mathrm{m} / \mathrm{d})$ \\
\hline
\end{tabular}

\section{Datum}

Vertical coordinate information is referenced to the National Geodetic Vertical Datum of 1929 (NGVD 29) and [or] the North American Vertical Datum of 1988 (NAVD 88). The original model used in this study is referenced to NGVD 29, but new groundwater-level measurements made for this study are referenced to NAVD 88.

Horizontal coordinate information is referenced to the North American Datum of 1983 (NAD 83). Altitude, as used in this report, refers to distance above the vertical datum.

\section{Abbreviations}

MAD mean-absolute difference

RMSE root-mean-squared error

USGS U.S. Geological Survey

WPAFB Wright-Patterson Air Force Base 



\title{
Update of the Groundwater Flow Model for the Great Miami Buried-Valley Aquifer in the Vicinity of Wright-Patterson Air Force Base near Dayton, Ohio
}

\author{
By Alexander D. Riddle
}

\section{Abstract}

A previously constructed numerical model simulating the regional groundwater flow system in the vicinity of the Wright-Patterson Air Force Base near Dayton, Ohio, was updated to incorporate current hydrologic stresses and conditions and improve the usefulness of the model for water-supply planning and protection. The original model, which simulated conditions from 1997 to 2001, was reconstructed with the most recently available U.S. Geological Survey groundwater modeling software and recalibrated to represent average groundwater flow conditions for the period of October 2018.

The steady-state, three-dimensional, three-layer MODFLOW model of the aquifer encompasses about 241 square miles in Montgomery, Greene, and Clark Counties. The Great Miami buried-valley aquifer consists of glacial sands and gravels in a buried bedrock valley. The shale bedrock in the area is poorly permeable, but the glacial deposits can yield as much as 2,000 gallons per minute to wells. As groundwater is the primary source of drinking water in the heavily populated study area, groundwater pumping from the buried-valley aquifer represents the largest time-varying stress in the groundwater flow model. The model simulated 228 pumped wells. Hydraulic conductivities in the model ranged from less than 1 foot per day to 450 feet per day. Simulated recharge rates ranged from 6 inches per year to 12.2 inches per year. Boundary conditions and aquifer properties were unchanged from the previous model. Model grid spacing and orientation also were not modified from the previous model.
Parameter estimation software was used to optimize model input parameters by matching simulated values to observed (estimated or measured) values. Calibrated parameters included horizontal hydraulic conductivity, vertical hydraulic conductivity, riverbed conductance, and recharge. Model calibration used measured water levels (hydraulic heads) from 124 observation wells, and streamflow gain/loss measurements from select reaches of the Mad River and its tributaries were compared with simulated streamflow gain/ loss. Performance of the updated model is similar to previous studies. Eighty-one percent of simulated hydraulic heads were within 10 feet of the measured hydraulic heads, but comparison of the simulated streamflow gain/loss with the measured gain/loss indicates that streamflow gain/loss is not well represented by the updated model.

The particle tracking program MODPATH was used to calculate groundwater flow paths from recharge areas to selected existing and proposed groundwater withdrawal sites that service Wright-Patterson Air Force Base. Areas contributing groundwater to withdrawal sites were delineated based on 1-, 5-, and 10-year groundwater travel times. In addition, groundwater flow paths were calculated to simulate a groundwater release at eight sites near Wright-Patterson Air Force Base.

\section{Introduction}

Increasing water demand in southwestern Ohio is met almost entirely by groundwater withdrawals (Dumouchelle, 1998). For public-supply drinking water, Greene County and Montgomery County ranked as the fourth and fifth largest 
groundwater-sourced water users by population served according to 2015 U.S. Geological Survey (USGS) water-use data (Dieter and others, 2018). The Great Miami buriedvalley aquifer, from which most of the substantial water users in the Dayton area withdraw groundwater, has been the subject of several groundwater investigations (Dumouchelle and others, 1993; Dumouchelle, 1998; Sheets, 1994; Sheets, 2007). The buried-valley aquifer was designated a solesource aquifer in 1988 (U.S. Environmental Protection Agency, 1993). The buried-valley aquifer, composed of Quaternary glacial sediments in the Great Miami River Basin, can yield more than 2,000 gallons per minute to wells (Dumouchelle, 1998) and provides groundwater to more than 60 registered Significant Water Withdrawal Facilities in Green and Montgomery Counties, extracting more than 152 million gallons per day (Mgal/d) (Ohio General Assembly, 2019).

Wright-Patterson Air Force Base (WPAFB or "the Base"), located just northeast of downtown Dayton, Ohio, encompasses parts of Montgomery and Greene Counties (fig. 1). Hydrogeologic investigations of groundwater flow near WPAFB have been ongoing since the early 1990s, when the USGS first partnered with WPAFB to simulate groundwater flow near the Base in an effort to identify and control migration of environmental contamination that may have resulted from past disposal practices (Dumouchelle, 1998).

Proper management of groundwater resources is aided by a thorough understanding of the groundwater flow system. The area of the Great Miami buried-valley aquifer near WPAFB is characterized by a large concentration of high-capacity public-supply wells in proximity to multiple potential sources of groundwater contamination (in the form of past and [or] present facilities and activities at the Base and in the surrounding urban setting). Effective source-water protection strategies rely on an up-to-date delineation of the areas that contribute groundwater to withdrawal sites. The Federal Government, through WPAFB, has an interest in maintaining water supplies for base personnel as part of base operations. The U.S. Air Force, the Base, and neighboring communities would benefit from having reproducible simulations to demonstrate groundwater source areas to regulators and public stakeholders and thereby facilitate continued base operations for national defense. To address this need, the USGS, in cooperation with the U.S. Air Force Civil Engineering Center, WPAFB, updated a previously published groundwater flow model (Sheets, 2007), which simulated conditions from 1997 to 2001 for the Great Miami buriedvalley aquifer.

\section{Purpose and Scope}

The purpose of this report is to document the updates to a previously constructed groundwater flow model (Sheets, 2007) in the vicinity of WPAFB near Dayton, Ohio. Updates to the original model were made to enhance understanding of the groundwater flow system based on the most recently available water-level and groundwater withdrawal data, improve the model performance, and improve the usefulness of the model for water-supply planning and protection.

Once the model had been updated and calibrated to observed conditions, areas contributing groundwater to select withdrawal sites were evaluated using MODPATH (Pollock, 2016). Backward tracking was used to calculate 1-, 5-, and 10-year groundwater flow paths from selected withdrawal sites backwards to where water recharges the aquifer.

Shifts in groundwater withdrawal rates and locations represent the most substantial changes to the model area. The original model (Sheets, 2007) used withdrawal rates collected between 1997 and 2001, simulating approximately $132 \mathrm{Mgal} / \mathrm{d}$ being pumped from 309 withdrawal sites. The updated model used reported withdrawal rates from 2018, simulating approximately $148 \mathrm{Mgal} / \mathrm{d}$ being pumped from 228 withdrawal sites.

The groundwater flow model was calibrated to the most recently available synoptic water-level data and groundwater withdrawal data where possible. Calibration data were collected from several sources; the primary source of calibration data consisted of water-level measurements (hydraulic head observations) collected from a selection of wells in the immediate vicinity of the Base during a synoptic event in October 2018. These data were supplemented with water levels from several USGS monitoring wells farther from the Base and water levels from select observation wells used in the original model collected between 1997 and 2001. Streamflow measurements made in the immediate vicinity of the Base in August 2019 were also used to assess model accuracy in simulating streamflow gain/loss but were not used in the calibration process. The groundwater flow model and supporting documentation are available as an online data release at https://doi.org/10.5066/ P9FN1JK4 (Riddle, 2021).

\section{Study Area Description}

The study area is in the Till Plains section of the Central Lowland Physiographic Province (Fenneman, 1938). The topography of the Till Plains is the result of continental glaciation; bedrock features formed by preglacial drainage systems were buried under glacial deposits. The result is a 


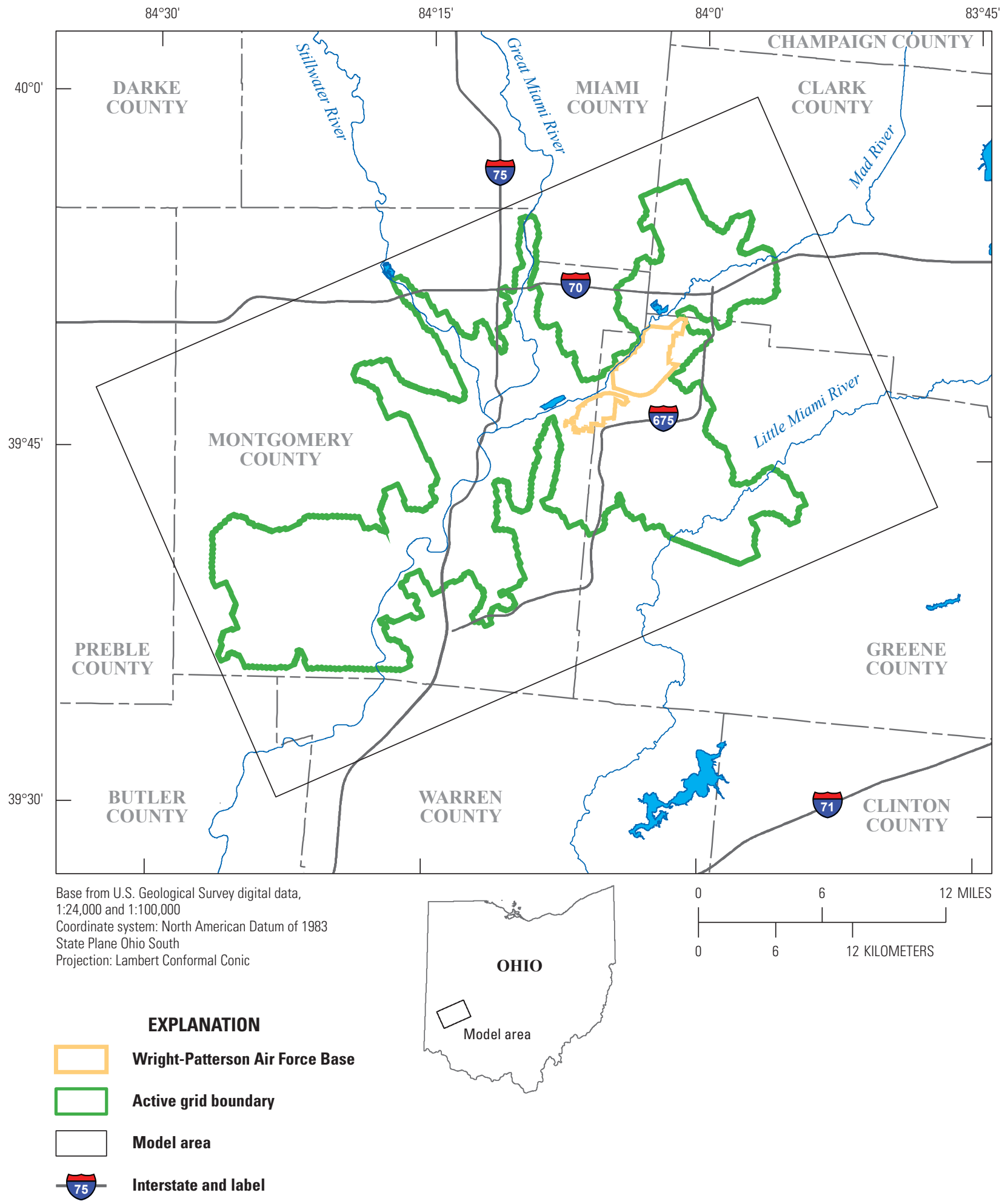

Figure 1. Overview map of the study area, showing the location of the Wright-Patterson Air Force Base within the model grid. 
land surface that is flat to gently rolling (Fenneman, 1938). Land-surface altitudes range from 690 feet $(\mathrm{ft})$ to more than $1,000 \mathrm{ft}$. The nearly flat floodplains of the major rivers - the Great Miami, Mad, Stillwater, and Little Miami-range in altitude from $690 \mathrm{ft}$ to $790 \mathrm{ft}$ along the Great Miami River to a maximum of $860 \mathrm{ft}$ in the northeast along the Mad River. Surface drainage through the study area is from north to south toward the Ohio River (not shown). In general, the upper reaches of the subbasins are agricultural, and the areas along the main drainages are suburban to urban. The city of Dayton is located at the confluence of the Great Miami, Stillwater, and Mad Rivers, at an altitude of about $750 \mathrm{ft}$.

\section{Groundwater Hydrology}

The buried valleys (such as the Great Miami buriedvalley aquifer) that underlie much of the study area were incised by glacial and preglacial drainage systems and may be as much as $300 \mathrm{ft}$ deep. Heterogeneous glacial deposits consisting of sands and gravels interbedded with till layers have filled the valleys. These sand and gravel deposits constitute the primary aquifer throughout the area. Reported hydraulic conductivities from aquifer tests led by various sources throughout the Dayton area generally range from 10 feet per day (ft/d) to approximately $500 \mathrm{ft} / \mathrm{d}$ (Dumouchelle, 1998). Hydraulic conductivities of less than $5 \mathrm{ft} / \mathrm{d}$ have been reported for silty and clay-rich deposits. The valley walls and floor consist of bedrock composed of Late Ordovician interbedded shales and limestones that are generally considered impermeable and form the base of the Great Miami buried-valley aquifer (Sheets, 2007). Early Silurian limestone bedrock in upland areas overlies the Ordovician rocks and can yield sufficient water for domestic purposes (Dumouchelle, 1998).

The Great Miami buried-valley aquifer receives recharge primarily in the form of precipitation and surfacewater infiltration (Sheets, 2007). Estimates of groundwater recharge from precipitation in the study area range from about 6 to 15.8 inches per year (Walton and Scudder, 1960; Panterra Associates, 1988; Dames \& Moore and others, 1992; Dumouchelle and others, 1993). Recharge to the buried-valley aquifer from surface-water infiltration can vary substantially over time, and inflow from the bedrock valley walls to the aquifer is considered negligible (Dumouchelle, 1998).

\section{Groundwater Flow Simulations}

The USGS first developed a three-layer groundwater flow model for parts of the study area in cooperation with WPAFB in 1993 to simulate hydraulic heads in the buried-valley aquifer and in an upland bedrock aquifer (Dumouchelle and others, 1993). The model area was centered on the Base, and the steady-state simulation indicated that groundwater entered the area primarily by river leakage and flow through the specified-flux cells at the model boundary and exited primarily by flow through the specified-flux cells at the opposite boundary and through production wells. Sheets (1994) and Cunningham and others (1994) used the steady-state model developed in 1993 to estimate groundwater flow pathlines and travel times to three active wellfields on the Base using an advective particle-tracking algorithm. Contributing groundwater areas were generated for 1-, 5-, and 10-year travel times. Pathlines for particles placed at the Base boundary and particles placed at sites of specific interest were also calculated and explained. In 1998, the USGS, in cooperation with the U.S. Environmental Protection Agency, developed a new steady-state groundwater flow model to simulate the regional groundwater flow system in the Dayton area in southwestern Ohio (Dumouchelle, 1998). The model area encompassed approximately 241 square miles in Montgomery, Greene, and Clark Counties and simulated steady-state conditions of September 1993 including 187 pumped wells. Sheets (2007) modified the model developed in 1998 to include several bedrock islands within the glacial valleys and recalibrated the model using automated parameter estimation techniques to represent average groundwater flow conditions for the period from 1997 to 2001 (herein referred to as "the original model"). Advective particle tracking simulations were used to compute areas contributing groundwater and travel times from recharge areas to 60 wells.

\section{Description of the Original Model}

The original model (Sheets, 2007) was developed using MODFLOW-2000 (Harbaugh and others, 2000; Hill and others, 2000). The model area encompassed approximately 240 square miles and was spatially discretized into 230 rows and 370 columns resulting in cell sizes of approximately 
500 by $500 \mathrm{ft}$. The model grid was rotated 25 degrees north of east, generally parallel to the Great Miami buriedvalley aquifer.

The buried-valley aquifer was simulated using three model layers of varying thickness (fig. 2). Layer 1 is simulated as unconfined, with the top representing the groundwater surface and bottom set to the altitude of the uppermost fine-grained layer where present, an equivalent altitude to the fine-grained layer, or the bedrock surface. Layers 2 and 3 were simulated as confined. The bottom of layer 2 was set to approximately $149 \mathrm{ft}$ below the estimated water level or the bedrock altitude. The thickness of layer 2 was chosen to limit the number of groundwater discharge sites screened in layer 3 , for which limited hydrogeologic data were available. The bedrock valley floor defined the bottom of layer 3 . Whereas layers 1,2 , and 3 explicitly represent the highly conductive sands and gravels of the aquifer, the fine-grained layers that are discontinuously present throughout the aquifer are represented implicitly by adjusting the vertical hydraulic conductivity of model cells where well logs indicate that an interbedded till or clay-rich layer is present.

Areal recharge from precipitation varies throughout the model domain, ranging from 5.9 to 12.2 inches per year. Initial recharge values were based on reported estimates from previous studies (Walton and Scudder, 1960; Panterra Associates, 1988; Dames \& Moore and others, 1992; Dumouchelle and others, 1993). Recharge values were spatially distributed in the model by delineating lowpermeability areas and relatively permeable areas based on surficial geology maps (Dumouchelle, 1998). Recharge rates were also manually adjusted in urban areas and along bedrock valley walls.

The multiple streams and rivers that run through the model domain are hydraulically connected to the buriedvalley aquifer and serve as both recharge and discharge locations for the model. The larger surface-water features were simulated with the MODFLOW River Package. Smaller intermittent streams were simulated with the MODFLOW Drain Package, which can only serve as a point of discharge for groundwater. River stage data and bottom altitude were determined from surveying, cross-sectional data, and estimates from USGS topographic maps. Values of riverbed hydraulic conductivity ranged from 0.3 to $14.1 \mathrm{ft} / \mathrm{d}$. Values of drain conductance ranged from 0.008 to 231.4 square feet per day. Initial estimates of riverbed hydraulic conductivity were based on results from other models in the area and seepage-meter tests (CH2M Hill, Inc., 1986; Geraghty \& Miller, Inc., 1987; CH2M Hill, Inc., 1989; Dumouchelle and others, 1993; Yost, 1995).

The model cells along the perimeter of the active model domain were represented by no-flow boundaries and specified-head cells. The no-flow boundaries simulated the contact between the aquifer deposits and the bedrock valley walls and floor. The specified-head boundary was used to represent down-valley flow into or out of the model area and were based on interpolation of groundwater-level contours from previous investigations (Dumouchelle and others, 1993). Where possible, specified-head boundaries were placed in narrow sections of the bedrock valley away from areas likely to be stressed in predictive simulations.

Upon completion of the manual calibration of the model, parameter estimation (Hill and others, 2000) was used to assess and improve performance of the model. Layer 1 of the model was divided into four zones representing different hydrologic conditions to evaluate each area's sensitivity to model input parameters. The four parameter estimation zones in the original model are (1) the main buried valley (BV); (2) the edge of the main buried valley (EDGE); (3) the upland areas (UP); and (4) the Oakwood area (OAK; fig. 3).

The root-mean-squared error (RMSE) and the meanabsolute difference (MAD), which are statistical measures of the variance and bias, respectively, were used to evaluate the model calibration. The RMSE was calculated as:

$$
R M S E=\sqrt{\frac{\sum_{i=1}^{N}\left(h_{\text {meas }}-h_{\text {sim }}\right) i^{2}}{N}}
$$

where

$$
\begin{aligned}
& h_{\text {meas }} \text { is the measured hydraulic head, } \\
& h_{\text {sim }} \text { is the simulated hydraulic head, } \\
&\left(h_{\text {meas }}-h_{\text {sim }}\right) \begin{array}{l}
\text { is the hydraulic head residual, and } \\
N
\end{array} \\
& \text { is the number of wells used in the } \\
& \text { computation. }
\end{aligned}
$$

The MAD was calculated using:

$$
M A D=\frac{\sum_{i=1}^{N} a b s\left(h_{\text {meas }}-h_{\text {sim }}\right) i}{N}
$$

where

$$
\begin{aligned}
& \text { abs indicates the absolute value of the } \\
& \text { expression. }
\end{aligned}
$$

The hydraulic heads calculated by the groundwater flow model were interpolated to their relative position within the grid cell. 


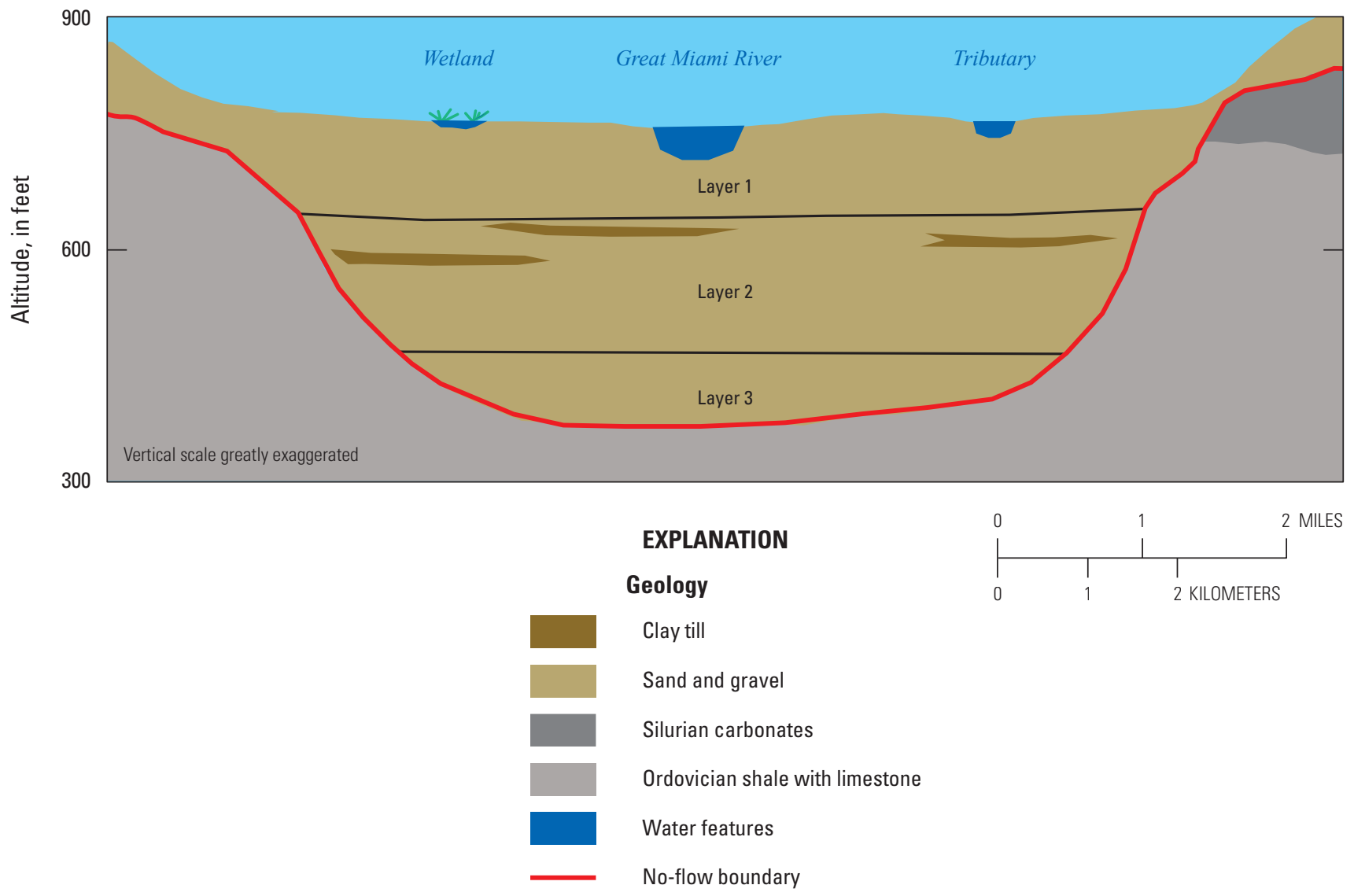

Figure 2. Schematic cross section of the groundwater flow model, Wright-Patterson Air Force Base, Ohio. (modified from Sheets, 2007). 


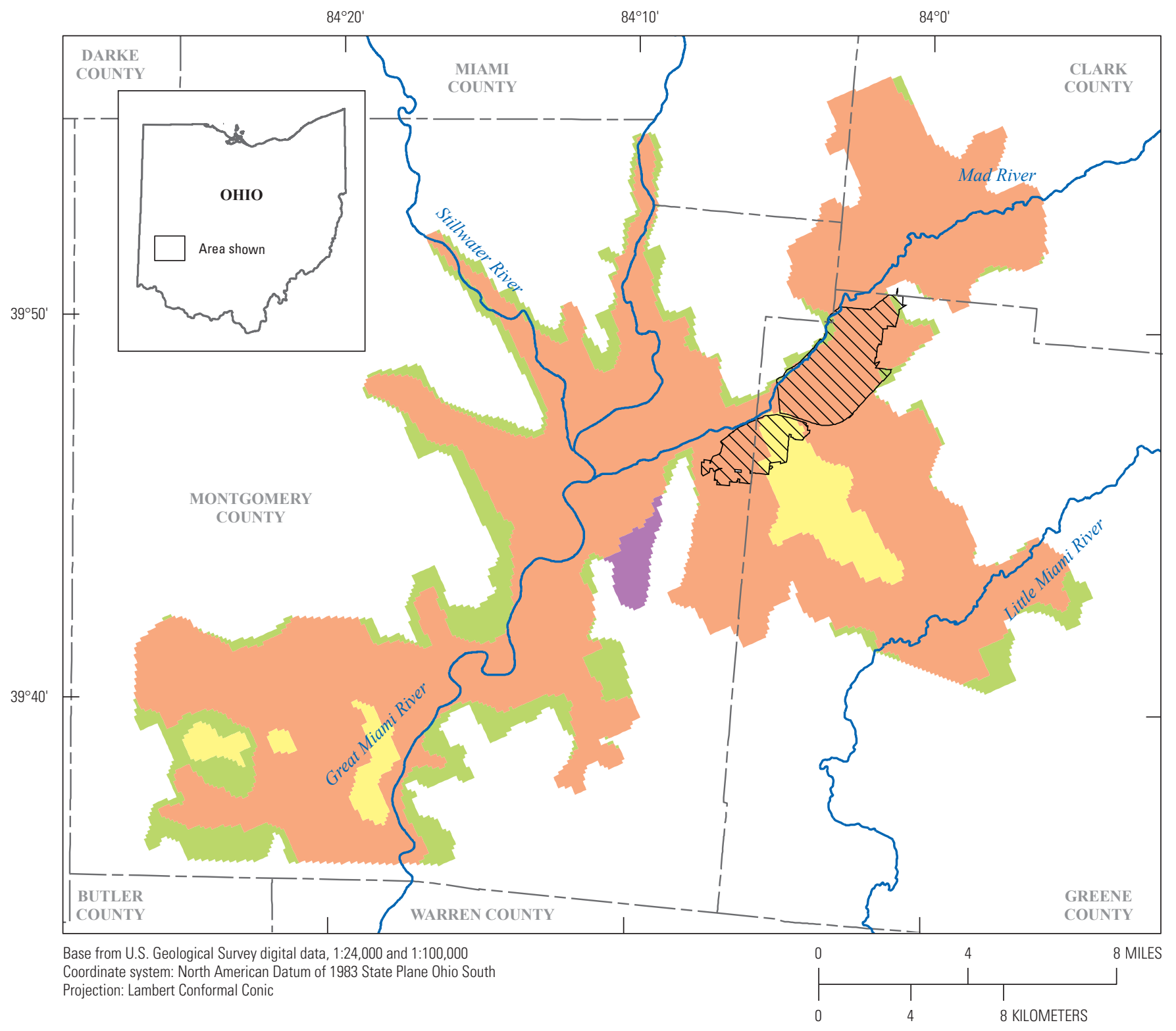

EXPLANATION

Parameter estimation zones

Wright-Patterson Air Force Base

\begin{tabular}{l|l|}
\hline Edge & Uplands \\
\hline Buried valley & Oakwood
\end{tabular}

Figure 3. Location of the parameter estimation zones for the original model (Sheets, 2007) and the updated model. 
Using the results of the parameter estimation process, Sheets (2007) compared observed and simulated water levels for: (1) 579 observation wells measured in 1993, and (2) 34 observation wells measured between 1997 and 2001. The resulting MAD was $5.45 \mathrm{ft}$ and $9.32 \mathrm{ft}$, respectively. The RMSE was $9.19 \mathrm{ft}$ and $13.12 \mathrm{ft}$, respectively.

\section{Description of Model Updates}

The initial step in updating the original model was reconstructing it in MODFLOW 6 (Langevin and others, 2017). Due to the different file structures and flow package requirements, model input files from MODFLOW-2000 were translated into files compatible with MODFLOW 6 with the aid of the conversion utility Mf5to6, provided in the MODFLOW 6 software release.

The finite-difference grid remained largely unchanged; model grid spacing and orientation were not modified from Sheets (2007). Representation of most boundary conditions (specified-head, recharge, rivers, and drains) for the steady-state updated model remained unchanged from Sheets (2007). Groundwater pumping rates were updated to those reported for October 2018. Pumping throughout the entire model domain increased from about 19.0 million cubic feet per day in the original model to 19.7 million cubic feet per day in the updated model. Except for the city of Dayton's production wells, pumping data were collected primarily from State of Ohio Water Withdrawal Facility Registration Annual Report Forms (Ohio General Assembly, 2019). Rates for wells providing water to the Base were calculated from the reported total withdrawal for each individual well for the month of October 2018 (Ohio General Assembly, 2019).

Pumping rates for Dayton's production wells were compiled from the city's most recent Source Water Protection Delineation Model Update (CH2MHill, 2011) that approximate 2018 pumping rates (J. Shoemaker, City of Dayton, written commun., 2020). The remainder of the withdrawal rates for pumping wells in the model domain were calculated from the reported total withdrawal for each water-supply facility for the month of October 2018 (Ohio General Assembly, 2019). Because reported values did not contain individual well rates, for many facilities reported pumping rates were for multiple wells instead of individual wells. If the wells for these facilities were within the same model cell, the provided total value was assigned as the single well boundary condition for the model cell. Where pumping rates were recorded as a single value and the facility wells were in multiple model cells, the provided pumping rate was apportioned evenly among cells.

Well locations, screen lengths, and model grid cells were used from Sheets (2007) where applicable. For the updated model, only facilities with the capacity to withdraw more than 100,000 gallons of water daily were included. Though smaller-capacity wells exist within the model domain and may have been included in the original model, the amount of water they withdraw is relatively insubstantial and would have few effects on the simulation.

New pumping wells (not previously included in the original model) were assigned to model layers based on the altitude of screen intervals with respect to the altitude of the model layers. Most screen intervals fell within a single model layer, but some wells had screens that intersected one or more model layers. In these cases, the well was assigned to the layer that contained at least 75 percent of the well screen length. Where neither model layer contained 75 percent of the well screen, the withdrawal rate was split evenly between the two layers.

Water-level data in the model domain were collected from multiple sources. Primary water-level data came from a synoptic measurement completed in October 2018 from 85 observation wells in the areas immediately surrounding the Base (table 1.1, appendix 1). This dataset was supplemented with water levels from 14 wells in the USGS statewide monitoring network farther from the Base. Water levels from October 2018 were obtained from the continuous record at 10 wells, and discrete water-level measurements were made at another 4 wells during August 2019. An additional dataset of 25 observation wells used in the original model, with water levels obtained between 1997 and 2001, was also included to increase the spatial distribution of calibration targets (table 1.1, appendix 1).

Due to the difference in measurement periods, the vertical datums of the observation well datasets did not match. Water-level altitudes collected from 1997 to 2001 are recorded in National Geodetic Vertical Datum of 1929 (NGVD 29); water-level altitudes collected from 2018 to 2019 are recorded in North American Vertical Datum of 1988 (NAVD 88). Altitude differences between NGVD 29 and NAVD 88 range from approximately 0.54 to $0.69 \mathrm{ft}$ in the model domain as determined from the National Geodetic Survey Coordinate Conversion and Transformation Tool (National Oceanic and Atmospheric Administration, 2021). A sensitivity analysis - which compared results from a model calibrated using the mixed datum water-level altitudes and 
a model calibrated using water-level altitudes converted to NGVD 29-concluded that changing observation measurement altitudes from one vertical datum to another did not substantially affect groundwater flow paths near the Base. The vertical datum of each set of measurements is detailed in appendix 1 .

Observation wells were assigned to model layers using the altitude of the screen interval. Where the screen interval intersected two model layers, the observation well was assigned to the layer with at least 75 percent of the screen interval. If no model layer contained at least 75 percent of the screen interval, the data from the observation well was not used.

\section{Performance of the Updated Model}

Upon reconstruction of the original model with MODFLOW 6, preliminary simulations were run using well distributions/pumping rates and observation targets from the original model to represent 1997-2001 hydrologic conditions. The resulting hydraulic heads output from the updated model were compared to those computed from the original model to ensure that the model was simulating the observed hydrologic conditions similarly (table 1 ).

The slight improvements in the statistical measures could be an effect of several changes made to the model during the conversion from MODFLOW-2000 to MODFLOW 6. The horizontal hydraulic conductivity at several model cells along the edges of the active model domain were adjusted to rectify numerical instability near the bedrock valley walls. In addition, unlike MODFLOW-2000, MODFLOW 6 does not support interpolation of observations within the model grid. This means that residuals are computed with the assumption that observation wells are in the center of the model cell.

\section{Conditions}

The updated model was calibrated to water-level observations for October 2018. Parameter estimation software (PEST++, version 5.0.10; White and others, 2020) was used to optimize model input parameters by matching simulated values to measured observations. Model calibration using PEST++ identifies an optimum set of model input parameters that minimizes the sum of the squared and weighted residuals where constraints can be placed on the ranges of parameter values and the relations among parameters (Doherty, 2010). Calibration parameters included horizontal hydraulic conductivity, vertical hydraulic conductivity, recharge, and riverbed conductance (table 2). These spatially variable parameters were adjusted using multipliers applied to each array. Horizontal hydraulic conductivity in model layer 1 and recharge are each divided into four parameter estimation zones (fig. 3) representing different hydrologic conditions to evaluate each area's sensitivity to model input parameters.

Before parameter estimation was done, $\mathrm{PEST}++$ was used to calculate composite scaled sensitivities (fig. 4) for all parameters, which can be used to evaluate whether the available observations provide enough information for parameter estimation (Hill and others, 2000). The most sensitive parameters in the updated model are shown in red on figure 4 and include riverbed conductance (RV), layer 2 horizon-tal conductivity (HK2), and recharge and layer 1 horizontal hydraulic conductivity in the buried valley (RCH BV, HK1 $\mathrm{BV}$ ), edges of the buried valley (RCH_EDGE, HK̄1_EDGE), and uplands ( $\left.\mathrm{RCH}_{-} \mathrm{UP}, \mathrm{HK} 1 \_\mathrm{UP}\right) . \mathrm{PEST}++$ was also used to determine that no identified sensitive parameters were highly correlated with each other. Thus, all eight parameters were optimized during parameter estimation. Due to the spatial bias of observation well locations, observation wells were selectively included as calibration targets in the parameter estimation to avoid overrepresenting any one area of the model. Although the area of interest for the updated model lies primarily around the Base, establishing a regular

Table 1. Comparison of root-mean-squared error and mean-absolute difference of measured and simulated hydraulic heads, and between the original groundwater flow model (Sheets, 2007) and the updated model, both calibrated to 1997-2001.

[N, number of observations; RMSE, root-mean-squared error in feet; MAD, mean-absolute difference in feet].

\begin{tabular}{llllc}
\hline & Model & N & RMSE & MAD \\
\hline Original model & 34 & 13.12 & 9.71 \\
Updated model & 34 & 12.14 & 8.35 \\
\hline
\end{tabular}


Table 2. Parameters used in construction of the updated groundwater flow model calibrated to October 2018.

\begin{tabular}{|c|c|c|c|c|c|}
\hline Parameter & Layer & Main buried valley & Edge of main buried valley & Uplands & Oakwood \\
\hline \multirow{2}{*}{$\begin{array}{l}\text { Horizontal hydraulic } \\
\text { conductivity }\end{array}$} & 1 & HK1_BV & HK1_EDGE & HK1_UP & HK1_OAK \\
\hline & 2 & HK2 & HK2 & HK2 & HK2 \\
\hline \multirow{2}{*}{$\begin{array}{l}\text { Vertical hydraulic } \\
\text { conductivity }\end{array}$} & 1 & VK1 & VK1 & VK1 & VK1 \\
\hline & 2 & $\mathrm{VK} 2$ & VK2 & VK2 & VK2 \\
\hline Recharge & & RCH_BV & RCH_EDGE & RCH_UP & RCH_OAK \\
\hline Riverbed conductance & & RV & $\mathrm{RV}$ & RV & $\mathrm{RV}$ \\
\hline
\end{tabular}

distribution of wells for calibration of the regional-scale model necessitated exclusion of clustered observation wells in developed areas.

Calibration targets near the Base were selected with the goal of informing the simulation of a regional potentiometric surface. In some areas, observation wells located near one another (as close as $25 \mathrm{ft}$ ) displayed water-level differences as much as $40 \mathrm{ft}$. In these cases, wells with water levels that deviated largely from the closest surrounding cells were removed, with the hypothesis that they represent local-scale flow that the updated model cannot reliably simulate due to its grid resolution. Low observation weights were applied to the remaining wells in these areas in the parameter estimation simulations, which indicates low confidence that these measurements accurately represent the regional water table. Observation wells with water-level measurements from 1997 to 2001 were also given low observation weights due to the possibility that these water levels have changed substantially since the measurement was made. In total, 124 calibration targets were used in the parameter estimation process (table 1.1, appendix 1).

Figure 5 shows the distribution of calibration target residuals across the entire model domain resulting from the parameter estimation. The sparse observation data in the areas southwest of WPAFB exhibit mostly negative residuals, indicating that the simulated water levels are higher than the observed water levels. The observation wells with the largest residuals are in the downtown Dayton area. Simulated water levels may not capture potential complex interactions between the urban setting and the confluence of the Mad and Great Miami Rivers.

The northeastern parts of the model exhibit a slightly less-skewed distribution of residuals, with most observation wells on the Base (fig. 6). Most residuals in the northern part of the Base (Area A) are $\pm 5 \mathrm{ft}$, with some observation wells exhibiting residuals in the $+5-20 \mathrm{ft}$ range. The cluster of positive residuals towards the eastern boundary of the Base could indicate that the movement of water along the bedrock valley walls is not simulated correctly; previous investigations have noted the potentially adverse effect of no-flow boundaries on the match between the measured and simulated hydraulic heads (Dumouchelle, 1998).

Area B is primarily in the Bedrock Uplands parameter estimation zone, and observation wells that were in this zone were excluded from the analysis because they were not considered representative of the buried-valley aquifer. Water levels for the uplands were not measured for the original model, but previous work at WPAFB indicates the groundwater potentiometric surface mimics land-surface topography in the uplands (Schalk, 1992). Groundwater flows outward from upland highs and toward the center of the major river valleys (Dumouchelle, 1998).

Figure 7, which presents graphs comparing simulated and measured hydraulic heads, shows that residuals are well dispersed around the 1:1 line for both the 1997-2001 conditions (fig. $7 A$ ) and the 2018 conditions (fig. $7 B$ ), indicating limited skewness. The 1:1 line shows where the results would plot if the simulated hydraulic heads exactly matched the measured hydraulic heads.

Streamflow measurements (table 3; fig. 8) were made in the immediate vicinity of the Base by the USGS in cooperation with the Air Force Civil Engineering Center in August 2019. Streamflow gain/loss were used to assess model accuracy but were not used as calibration targets for parameter estimation. Comparison of the measured gain/ loss with the simulated gain/loss indicates that streamflow gain/loss is not simulated well by the updated model. This can be attributed to several factors, most notably the time 


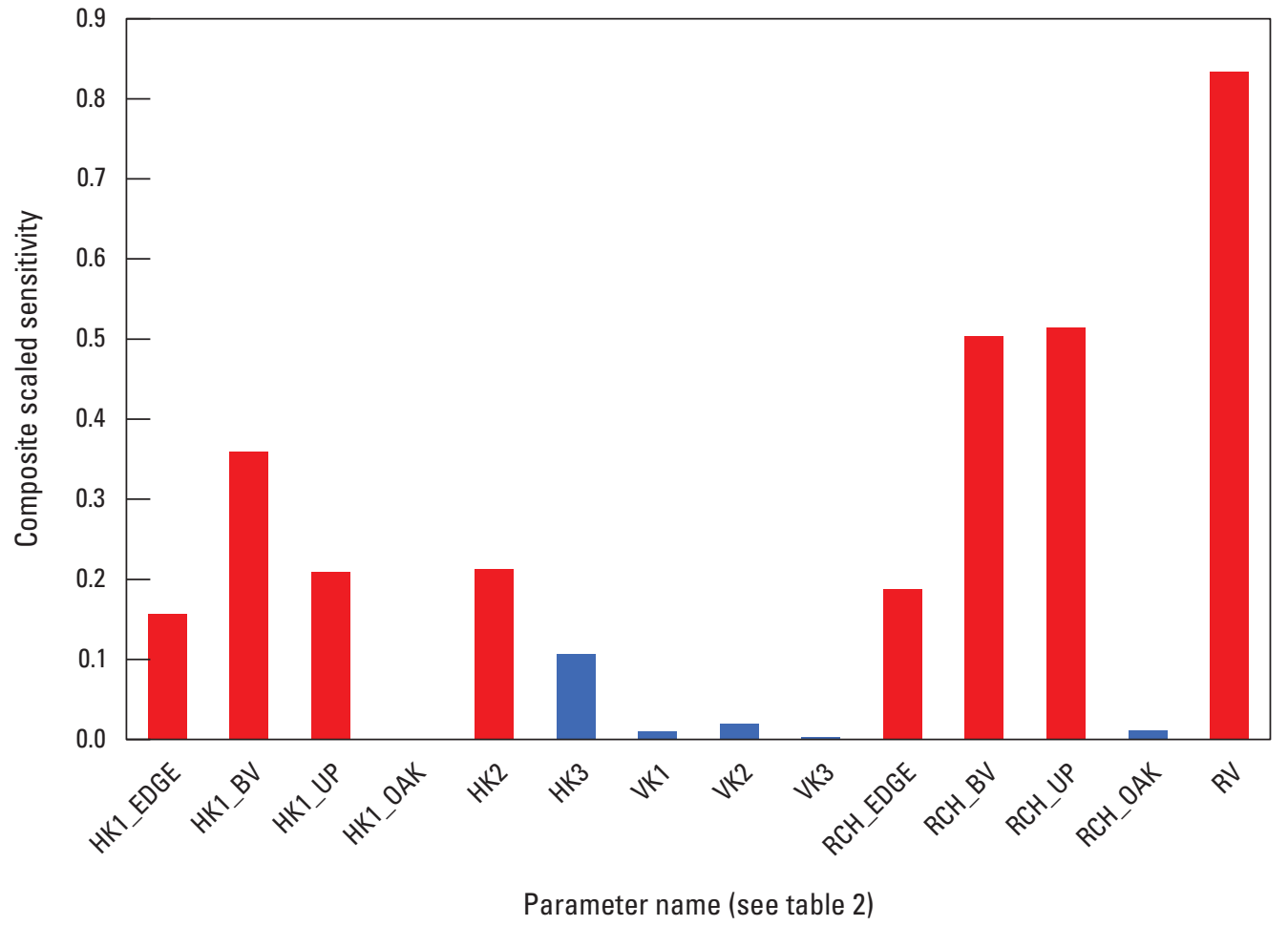

Figure 4. Composite scaled sensitivity of groundwater flow model parameters. Parameters in red were optimized during the parameter estimation process. Parameters in blue were held constant. 


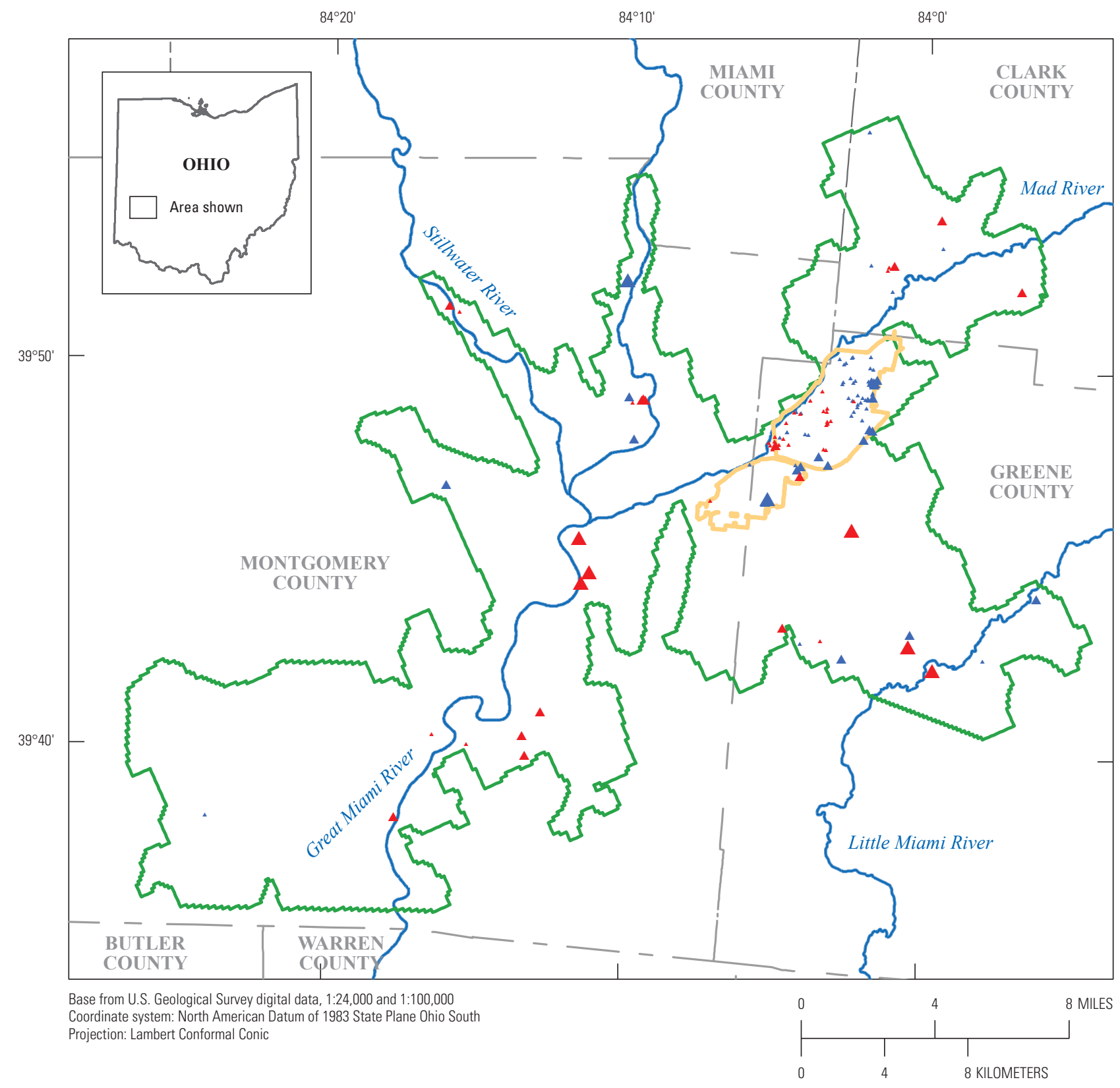

EXPLANATION

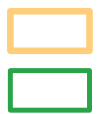

Wright-Patterson Air Force Base

Water-level difference, in feet

Active grid boundary

$\begin{array}{llll}\Delta & 20 \text { to } 45 & -5 \text { to } 0 \\ & 5 \text { to } 20 & -20 \text { to }-5 \\ & 0 \text { to } 5 & -45 \text { to }-20\end{array}$

Figure 5. Difference between observed water levels and simulated water levels for the entire model domain. Negative residuals (red) indicate simulated water-level altitudes greater than observed water-level altitudes, whereas positive residuals (blue) indicate simulated water-level altitudes less than observed water-level altitudes. 


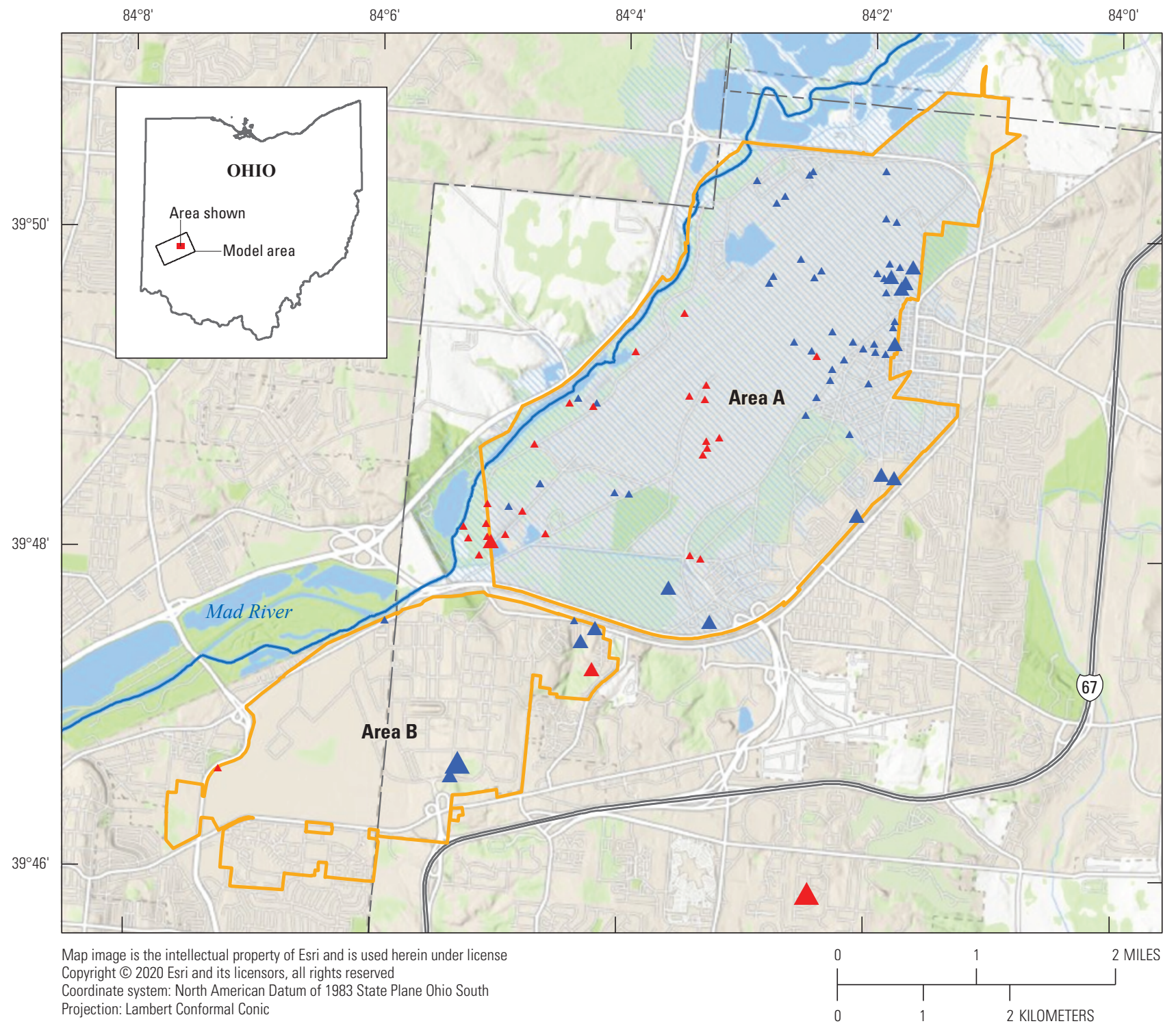

EXPLANATION

Wright-Patterson Air Force Base

Water-level difference, in feet

$\begin{array}{lll}\mathbf{4} & 20 \text { to } 45 & -5 \text { to } 0 \\ & 5 \text { to } 20 & -20 \text { to }-5 \\ - & 0 \text { to } 5 & -45 \text { to }-20\end{array}$

Figure 6. Difference between observed water-level altitudes and simulated water-level altitudes near the Wright-Patterson Air Force Base. Negative residuals (red) indicate simulated water-level altitudes greater than observed water-level altitudes, whereas positive residuals (blue) indicate simulated water-level altitudes less than observed water-level altitudes. 

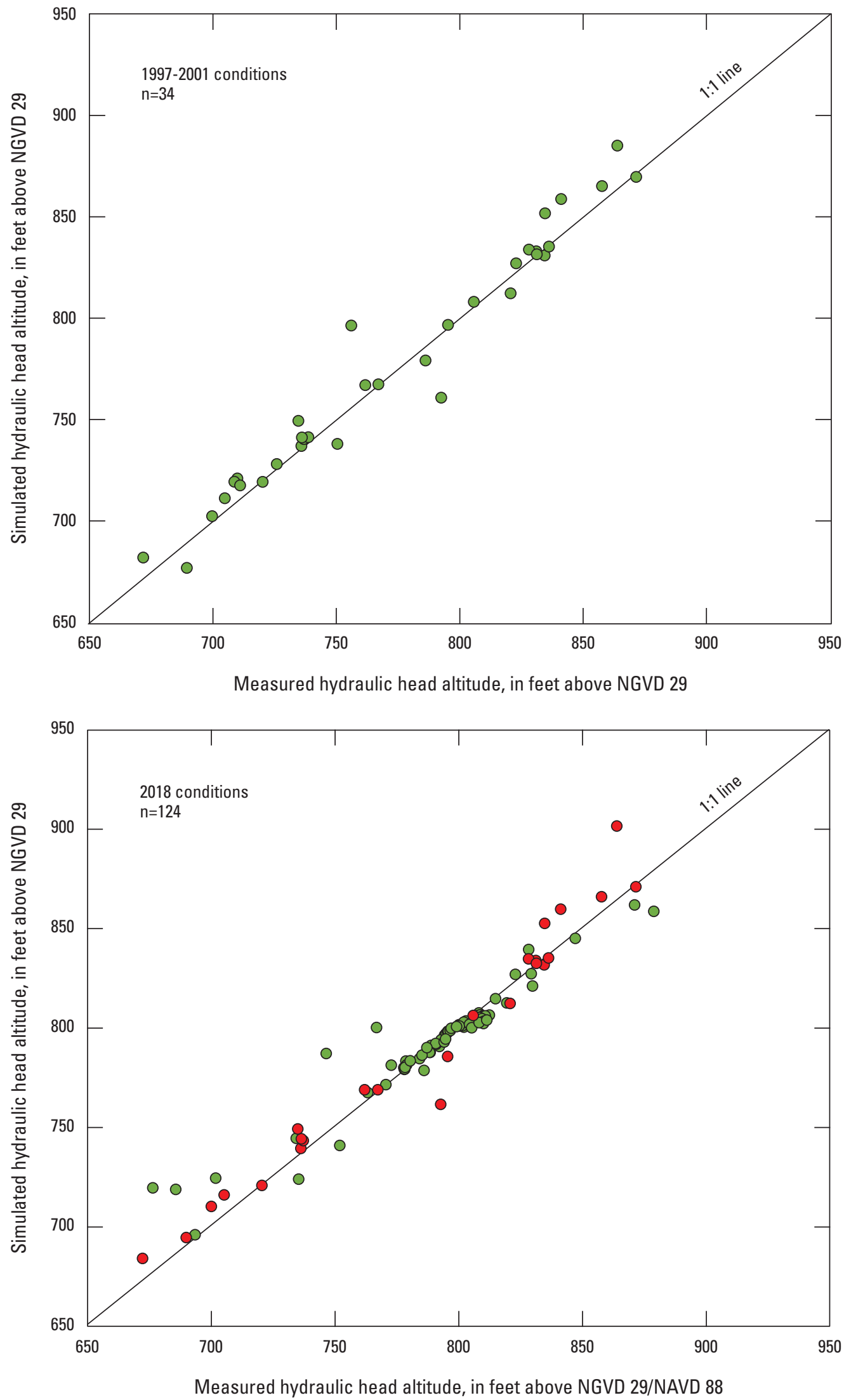

EXPLANATION

○ North American Vertical Datum of 1988

North Geodetic Vertical Datum of 1929

Figure 7. Relation between simulated and measured hydraulic heads for the updated model simulating, $A, 1997-2001$ conditions, and, $B, 0$ ctober 2018 conditions. 
Table 3. Comparison of measured and simulated streamflow gain or loss for the updated model, Great Miami buried-valley aquifer.

[units in $\mathrm{ft}^{3} / \mathrm{d}$, cubic feet per day; positive gain/loss values indicate groundwater discharge into the river; negative gain/loss values indicate recharge to the buried-valley aquifer]

\begin{tabular}{lll}
\hline \multicolumn{1}{c}{ Stream reach } & \multicolumn{2}{c}{ Streamflow gain or loss (2019) } \\
\cline { 2 - 3 } & Measured & Simulated \\
\hline Mad River, SR-235 to Bass Lake & $-6.91 \times 10^{5}$ & $-4.14 \times 10^{5}$ \\
Hebble Creek, WPAFB to Mad River & $-7.78 \times 10^{4}$ & $+4.89 \times 10^{4}$ \\
Hebble Creek, Memorial Rd. to west of SR-444 & $-1.73 \times 10^{4}$ & $+3.99 \times 10^{4}$ \\
Unnamed tributary to Mad River, Bayou Rd. to Marl Rd & $+1.73 \times 10^{4}$ & $-9.55 \times 10^{4}$ \\
\hline
\end{tabular}

discrepancy between measurements (August 2019) and calibrated time period (October 2018). Although the comparison does indicate similarities between measured and simulated flows for the perennial Mad River (both indicate a losing reach), smaller streams such as Hebble Creek, which do not interact closely with the regional flow system (Dumouchelle and others, 1993), exhibit a poor fit between measured and simulated flows.

\section{Simulated Water Budget}

Table 4 presents a comparison of the volumetric water budgets for the original model and the updated model. Eighty-five percent of simulated hydraulic heads were within $10 \mathrm{ft}$ of the measured hydraulic heads. The RMSE and MAD between measured and simulated hydraulic heads were $9.83 \mathrm{ft}$ and $5.60 \mathrm{ft}$, respectively. Recharge and river leakage accounts for approximately 77 percent of the water entering the model; pumped wells and river leakage accounts for more than 94 percent of the groundwater leaving the model.

The simulated potentiometric surface for the updated model calibrated to October 2018 is presented in figure 9. The potentiometric surface is relatively high in the northeast parts of the aquifer and gradually decreases to the southwest, eventually flattening out through the main trunk of the buried valley to the west of WPAFB and through downtown Dayton. Bedrock uplands to the south of the Base (and less extensively in the far southwest parts of the model domain) exhibit the highest simulated potentiometric surface in the model.

\section{Particle Tracking}

The particle-tracking software MODPATH (Pollock, 2016) was used to calculate groundwater flow paths and travel times for multiple hydrologic conditions. MODPATH utilizes hydraulic heads and flow distribution computed from the updated MODFLOW model. Sheets (2007) used an effective porosity (required by the particle-tracking program) of 0.2 for all model layers; this was deemed reasonable for the study area based on previous work (Cunningham and others, 1994) and was used in the updated model. Although estimates of porosity for unconsolidated media can vary substantially, preliminary particle tracking simulations using the updated model revealed that higher porosity values did shorten the distance a particle traveled through the groundwater system for a given travel time, but higher porosity did not alter the particle's path. Therefore, the conservative approach to addressing the uncertainty associated with choosing a porosity value for this simulation was to accept the estimate of 0.2 , knowing that higher estimates would also be represented in the produced groundwater contributing area.

\section{Existing Groundwater Withdrawal Sites}

The updated groundwater flow model was used to delineate areas contributing groundwater for 13 existing groundwater withdrawal sites servicing WPAFB. Backward tracking was used to calculate 1-, 5-, and 10-year groundwater flow paths; groundwater particles were tracked backward from the groundwater withdrawal site to where it recharges 


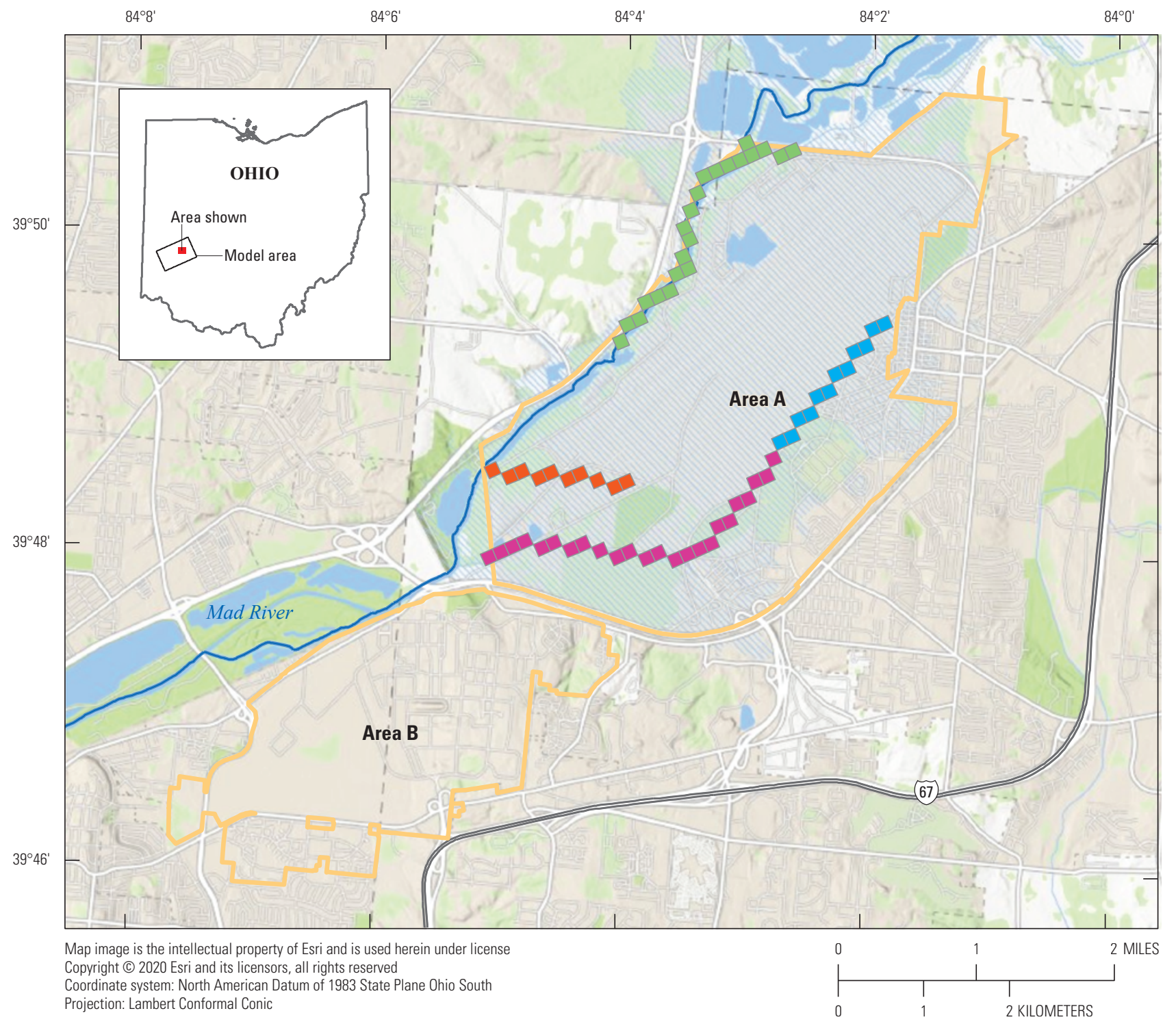

EXPLANATION

\section{Flow observations}

Wright-Patterson Air Force Base

Hebble Creek, Memorial Road to West of State Route 444

Hebble Creek, Wright-Patterson Air Force Base to Mad River
Mad River, State Route 235

$$
\text { to Bass Lake }
$$

Unnamed tributary to Mad River, Bayou Road to Marl Road

Figure 8. Location of stream reaches shown as model cells where streamflow gain/loss was determined from measurements made during August 2019. 
Table 4. Volumetric water budget comparison for original model and the updated model.

$\left[\mathrm{ft}^{3} / \mathrm{d}\right.$, cubic feet per day]

\begin{tabular}{lcc}
\hline \multicolumn{1}{c}{ Model inflow } & Original $\left(\mathbf{f t} \mathbf{t}^{3} / \mathbf{d}\right)$ & Updated $\left(\mathbf{f t}^{3} / \mathbf{d}\right)$ \\
\hline Rivers & $1.38 \times 10^{7}$ & $1.66 \times 10^{7}$ \\
Down-valley flow into model area & $7.91 \times 10^{6}$ & $8.51 \times 10^{6}$ \\
Recharge from precipitation & $1.38 \times 10^{7}$ & $1.09 \times 10^{7}$ \\
Total & $3.55 \times 10^{7}$ & $3.60 \times 10^{7}$ \\
\hline \multicolumn{1}{c}{ Model outflow } & \\
\hline Down-valley flow out of model area & $2.26 \times 10^{6}$ & $1.93 \times 10^{6}$ \\
Discharge to withdrawal sites & $1.90 \times 10^{7}$ & $1.97 \times 10^{7}$ \\
River and drains & $1.42 \times 10^{7}$ & $1.44 \times 10^{7}$ \\
Total & $3.55 \times 10^{7}$ & $3.60 \times 10^{7}$ \\
\hline
\end{tabular}

the water table and enters the groundwater flow system (for example at the water table surface, a river cell, or a specifiedhead cell). Flow paths defined the contributing groundwater areas (the three-dimensional volumetric parts of the aquifer through which groundwater flows to a withdrawal site) projected up to the land surface.

In an effort to account for potential increases in pumping, the annual total withdrawal from 2019 (as determined from the State of Ohio Water Withdrawal Facility Registration Annual Report Forms) for each WPAFB groundwater withdrawal site was identified, increased by 5 percent, and expressed as a daily pumping rate (table 1.2, appendix 1). The contributing groundwater areas are presented in figures 10 and 11.

The groundwater contributing areas indicate that, in general, the direction of groundwater flow is strongly affected by the withdrawal site's proximity to the Mad River and the orientation of the buried valley. The withdrawal sites farthest removed from the river (to the northeast in Area A) exhibit contributing areas oriented more parallel with the river's flow direction (northeast to southwest). Withdrawal sites closer to the Mad River where the simulated buried valley begins to narrow (constrained by the bedrock uplands to the south) exhibit contributing areas oriented nearly perpendicular to the river, with groundwater flow path directions both towards the river and away (where groundwater withdrawal sites are simulating induced recharge).

\section{Proposed Groundwater Withdrawal Sites}

The updated groundwater flow model was also used to delineate areas contributing groundwater to eight proposed groundwater withdrawal sites on the Base. These proposed withdrawal sites were simulated at varied depths and pumping rates, mirroring the existing withdrawal sites servicing WPAFB (table 1.3, appendix 1). The contributing groundwater areas are presented in figures 12 and 13 and exhibit somewhat similar patterns to the contributing groundwater areas of the existing withdrawal sites. Groundwater flow pathlines vary between parallel and perpendicular to the Mad River's flow direction in the northeastern areas of the Base, whereas pathlines for withdrawal sites in Area B induce recharge from the Mad River.

\section{Simulated Release Areas}

The updated groundwater flow model was also used to simulate the fate of particles that may enter the groundwater system at potential release locations near the Base. Using the forward tracking abilities of MODPATH, the migration of particles through the simulated aquifer can be traced into the future for any specified amount of time or until they exit the groundwater flow system (for example at a river cell, specified-head cell, or simulated pumping well; table 5). Particles were placed at the simulated water table rather than 


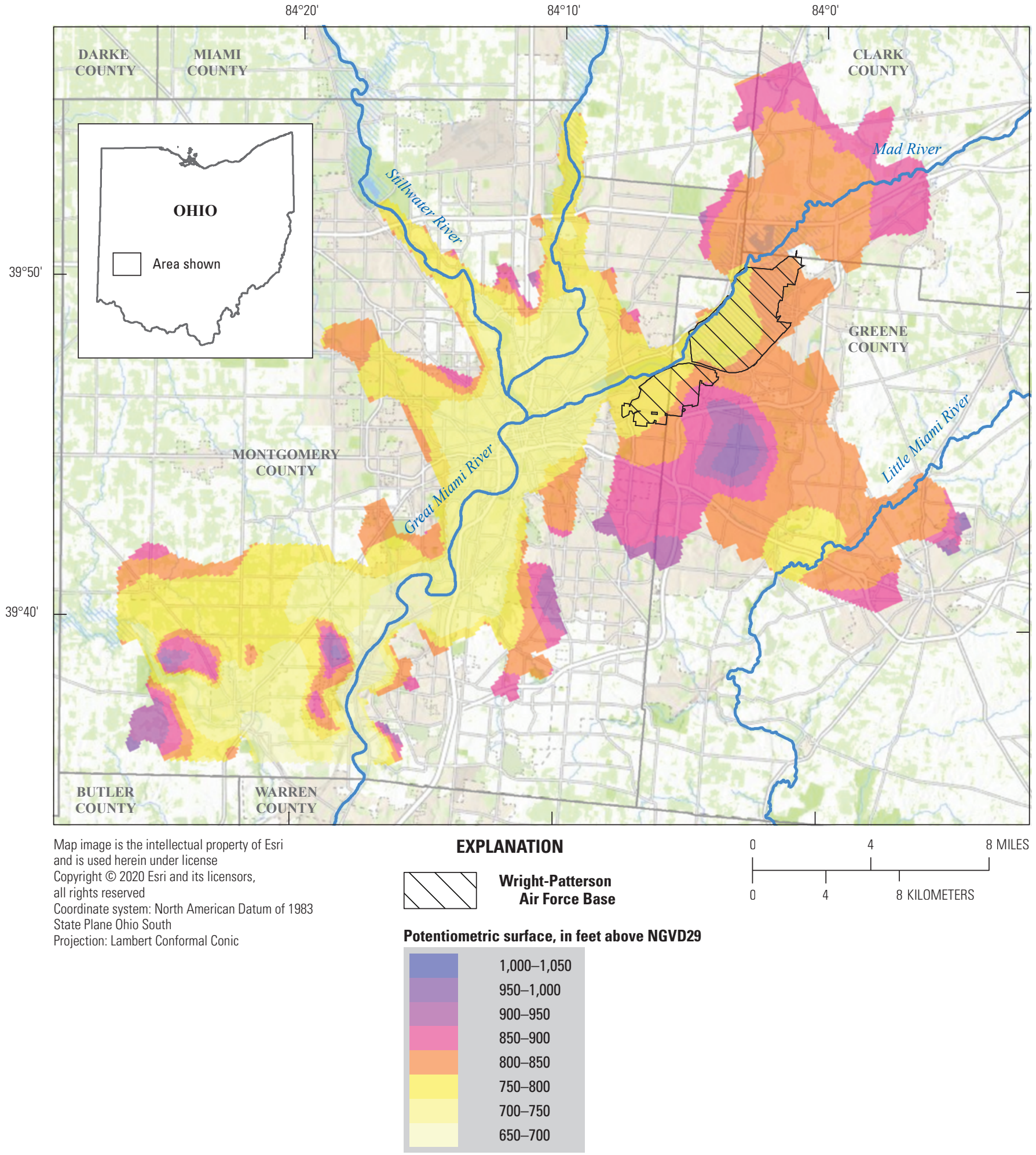

Figure 9. Simulated altitude of potentiometric surface of the Great Miami buried-valley aquifer, calibrated to 0ctober 2018. The general direction of groundwater flow is from northeast to southwest. 


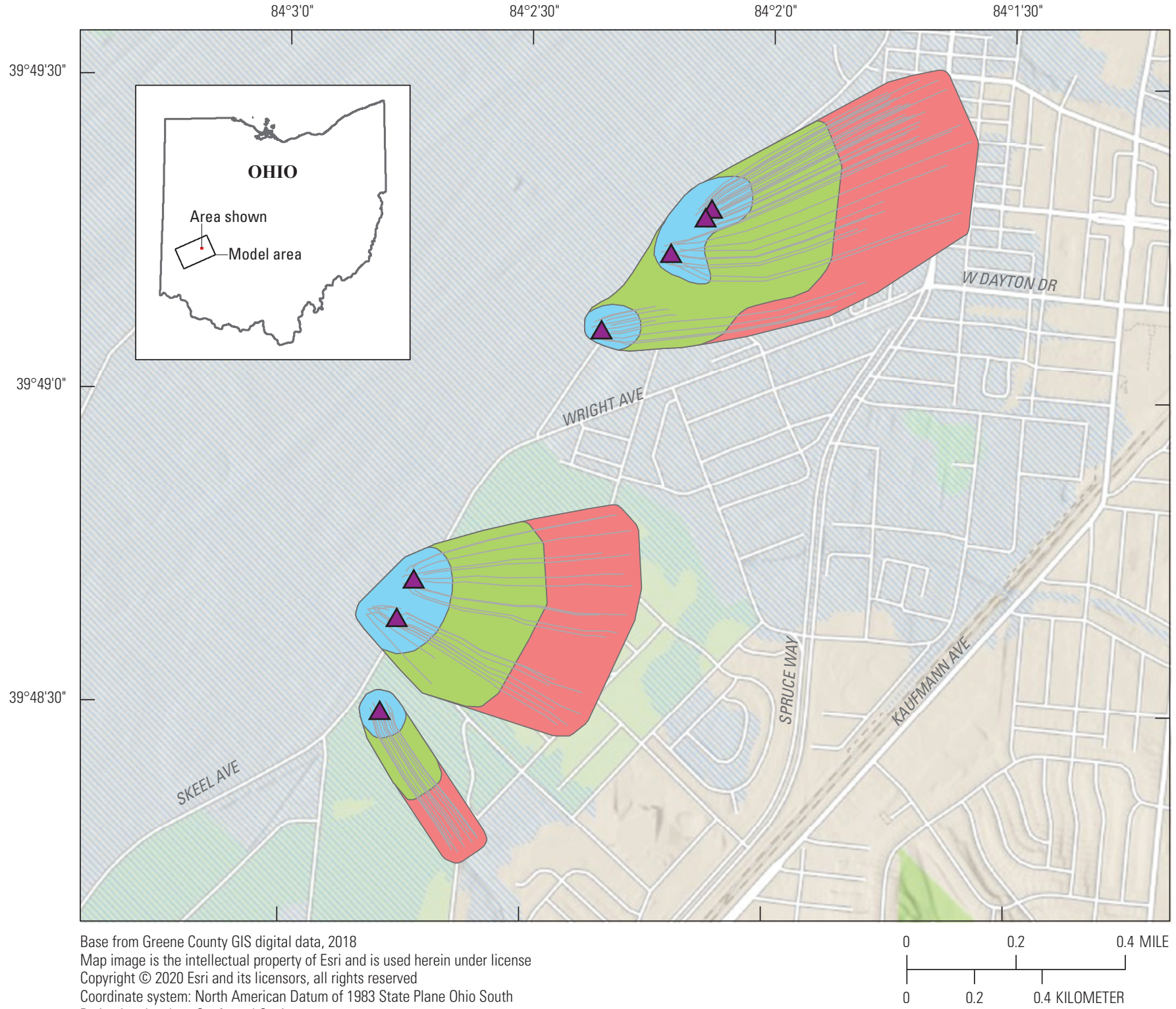

erican Datum of 1983 State Plane Ohio South

Projection: Lambert Conformal Conic

\section{EXPLANATION}

Groundwater contributing areas

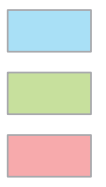
1-year time-of-travel
5-year time-of-travel
10-year time-of-trave

\section{Groundwater flow pathlines}

$\triangle \quad$ Groundwater withdrawal site

Figure 10. 1-,5-, and 10-year contributing groundwater areas for groundwater withdrawal sites in Area A, Wright-Patterson Air Force Base. 


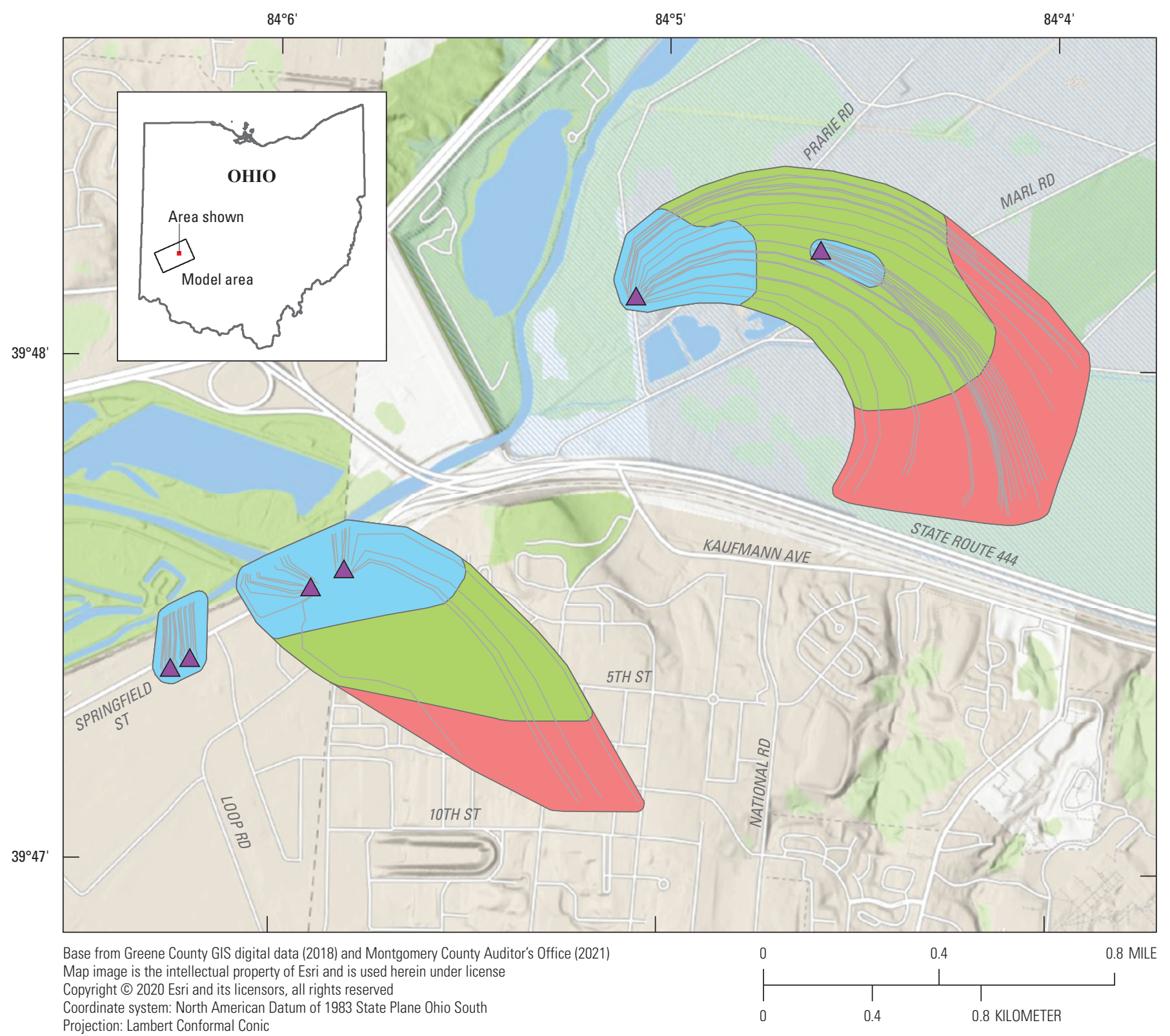

\section{EXPLANATION}

\section{Groundwater contributing areas}

1-year time-of-travel

5-year time-of-travel

10-year time-of-travel
Groundwater flow pathlines

Groundwater withdrawal site

Figure 11. 1-, 5-, and 10-year contributing groundwater areas for groundwater withdrawal sites in Area $A$ and Area $B$, Wright-Patterson Air Force Base (see fig. 6 for locations of Area A and Area B). Note that all groundwater that is contributed to the sites in the southwest corner of the map has a time-of-travel less than 1 year, hence the absence of a 5- and 10-year area. 


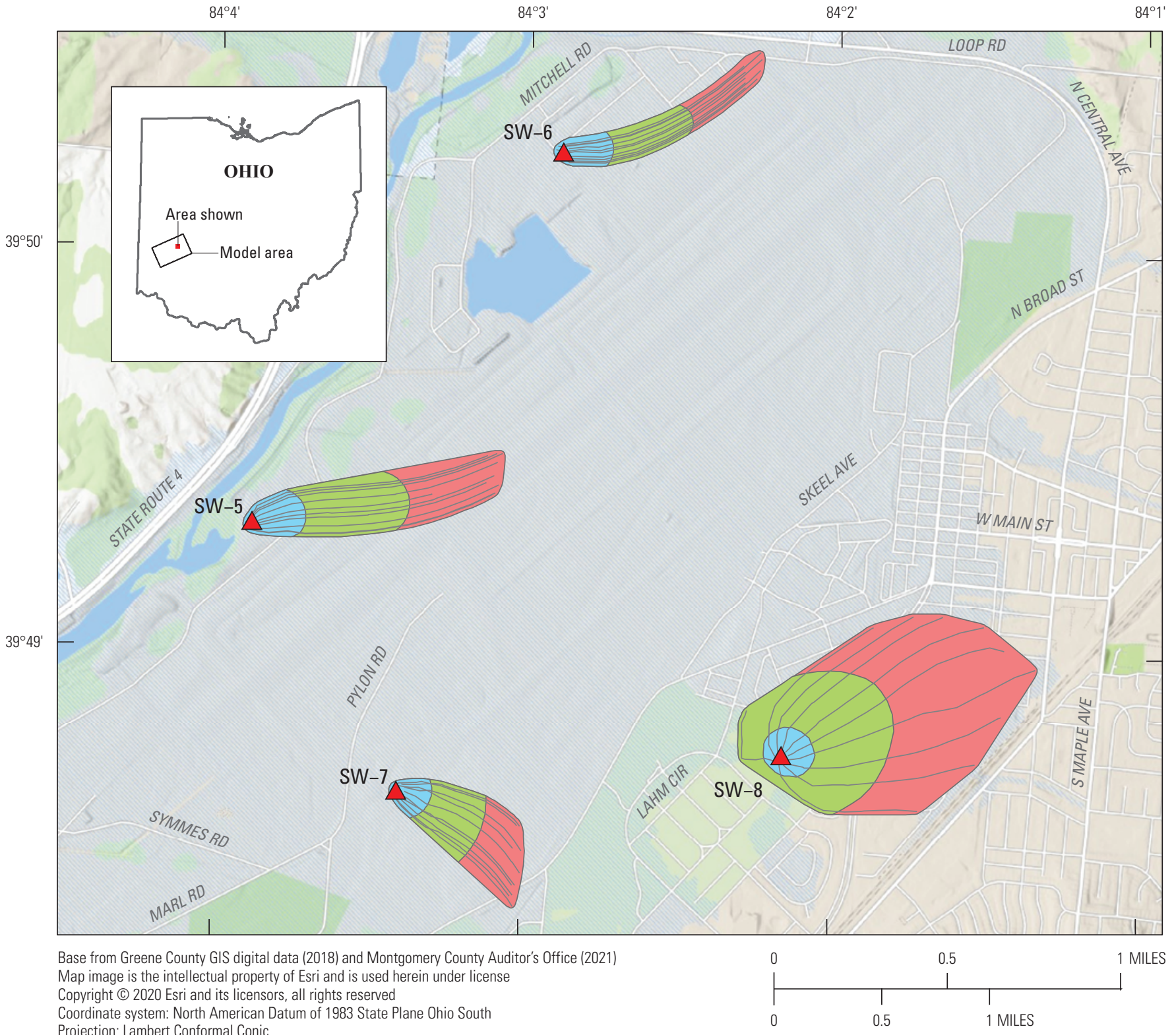

Projection: Lambert Conformal Conic

\section{EXPLANATION}

Groundwater contributing areas

1-year time-of-travel

5-year time-of-trave

10-year time-of-travel
Groundwater flow pathlines

$\triangle \quad$ Proposed groundwater withdrawal site

Figure 12. 1-, 5-, and 10-year contributing groundwater areas for proposed groundwater withdrawal sites in Area A, Wright-Patterson Air Force Base. 


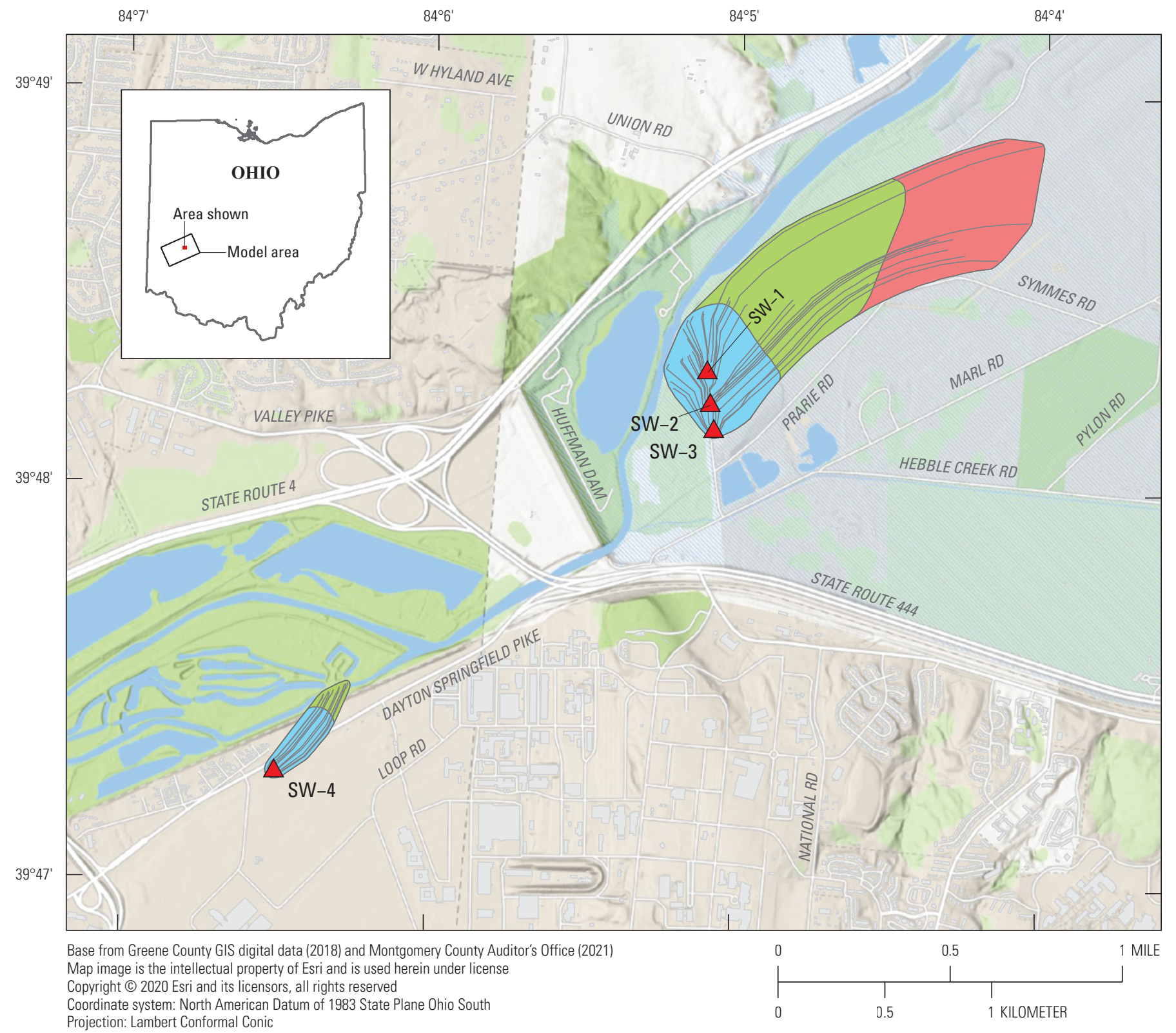

EXPLANATION

Groundwater contributing areas

1-year time-of-travel

5-year time-of-travel

10-year time-of-travel
Groundwater flow pathlines

Proposed groundwater withdrawal site

Figure 13. 1-, 5-, and 10-year contributing groundwater areas for proposed groundwater withdrawal sites in Area $A$ and Area $B$, Wright-Patterson Air Force Base (see fig. 6 for locations of Area A and Area B). 
Table 5. Calculated average travel time to discharge for eight simulated release areas, Wright-Patterson Air Force Base.

\begin{tabular}{lc}
\hline \multicolumn{1}{c}{ Simulated groundwater release location } & Average travel time to discharge (days) \\
\hline Hangar 4020 & 1,267 \\
Building 60 & $3,650^{\mathrm{a}}$ \\
Buildings 478/479 & $3,650^{\mathrm{a}}$ \\
WPAFB Fire Training Area & 296 \\
Hazmat Pad 3 & 3,186 \\
Trey Landfill & 2,210 \\
City of Dayton Fire Training Area & $3,650^{\mathrm{a}}$ \\
Outfall 1 & 2,640 \\
\hline
\end{tabular}

aParticles released at these areas were not discharged and remained in the groundwater system after 3,650 days.

the ground surface, as contaminant transport through the unsaturated zone (and its associated degradation and (or) dispersion) is beyond the scope of the study.

Figures 14 through 18 indicate that although groundwater particles typically discharge at the simulated river cells, proximity to a river does not always correlate to a short average travel time to discharge. Groundwater flow velocity may be particularly slow, as is the case with Building 60 (fig. 15). Trey Landfill and Outfall 1 exhibit some particles that travel beneath the adjacent river cell rather than discharging, as losing reaches of the river will recharge the aquifer (fig. 18). Where no groundwater discharge point is near, particles continue to follow the direction of groundwater flow, which occurs as particles released at Building 478/479 continue to move toward the Mad River at the end of the MODPATH simulation (fig. 16).

\section{Model Limitations and Uncertainties}

The limitations of the updated model are much the same as the limitations of the original model (Sheets, 2007). Although the model uses justifiable aquifer properties and boundary conditions obtained from previous hydrogeologic investigations of the Base, the groundwater flow model serves as a nonunique representation of the flow system, because acceptable results may be produced from any number of reasonable variations in the hydrogeologic properties.
The original model had a much broader focus than the updated model, examining contributing groundwater areas to numerous wells and groundwater travel times for a large part of the Great Miami buried-valley aquifer. For the updated model, as the focus is narrowed to the Base and the surrounding wellfields, the size of the model grid cells becomes more important. Small-scale changes and observations in the flow paths may be lost due to the coarse grid resolution. The grid size also affects the calibration process, as multiple hydraulic head observations were collected within the boundaries of a single grid cell, but only one water-level value per model cell can be used as a calibration target. Uncertainty stemming from vertical datum differences in the water-level measurements was considered in the weighting of observation targets, but the small altitude shifts that would result from this are negligible in comparison with the grid cell size and regional scale of the model.

The uneven distribution of hydraulic head observations throughout the model domain may also have an adverse effect on the calibrated potentiometric surface, as there were a disproportionately large number of observations in the immediate vicinity of the Base, compared to the relatively few observations throughout the rest of the model domain.

Computed areas contributing groundwater and travel times are based on the advective movement of water through the aquifer; chemical and biological attenuation, solid-phase portioning, dispersion, and diffusion are not represented by this simulation. Computed areas contributing groundwater and travel times are also based on a constant assumed 


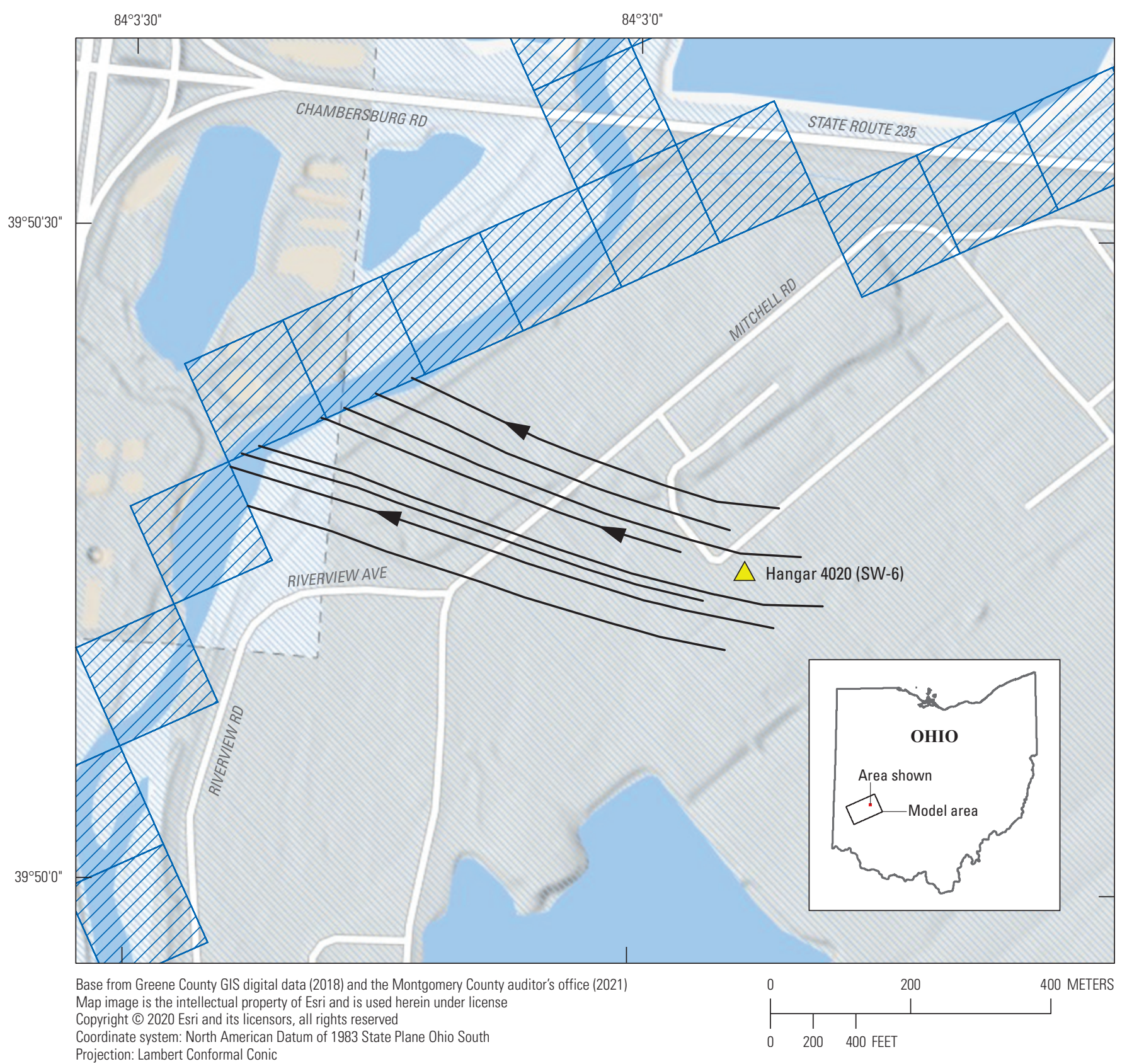

Coordinate system: North American Datum of 1983 State Plane Ohio South

\section{EXPLANATION}

Z/A Simulated river cells

Groundwater flow pathlines

$\triangle \quad$ Simulated release area

Figure 14. Particle pathlines for a simulated groundwater release at Hangar 4020, Wright-Patterson Air Force Base. 


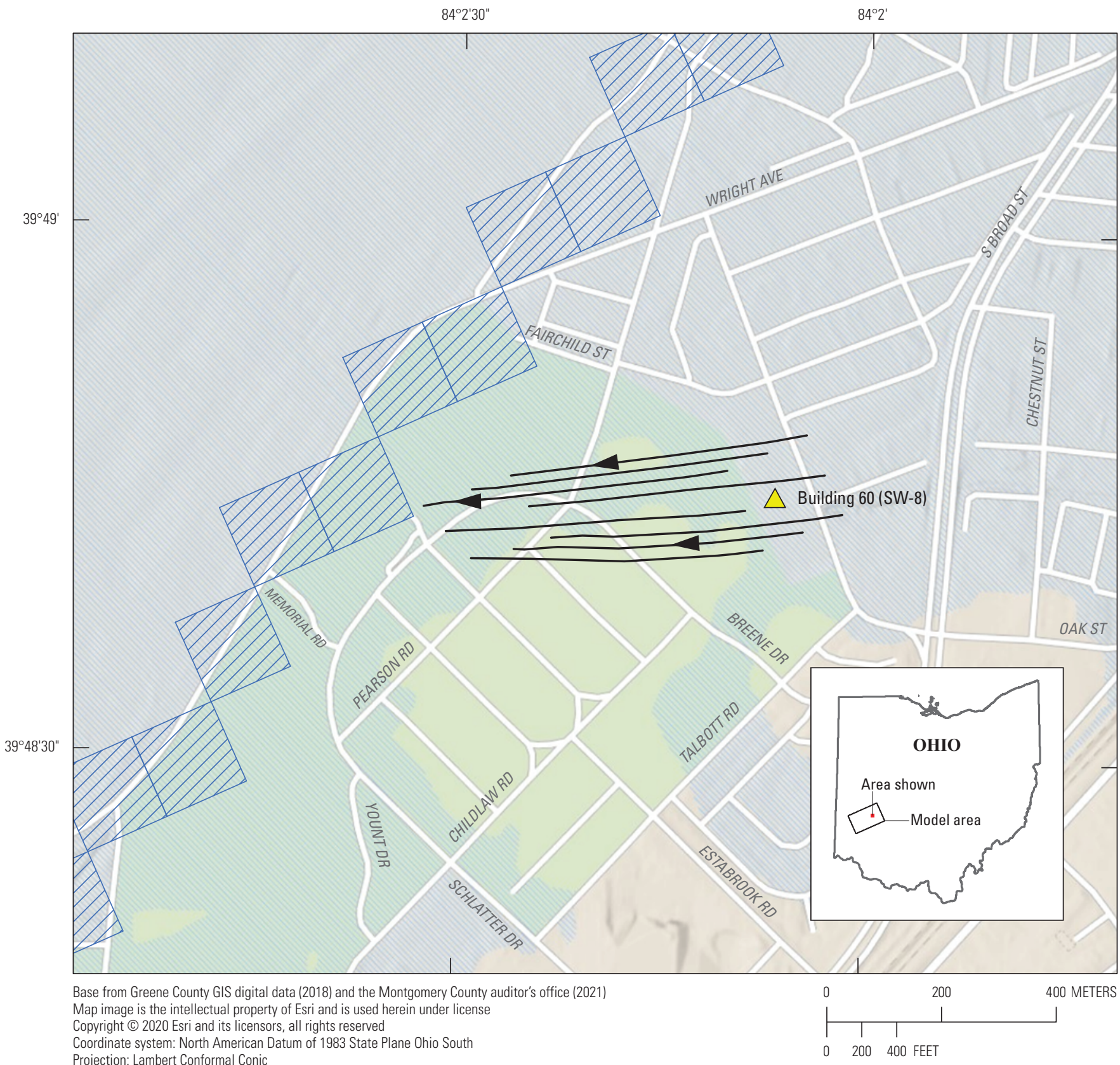

Projection: Lambert Conformal Conic

EXPLANATION

Simulated river cells

$\triangle \quad$ Simulated release area

Figure 15. Particle pathlines for a simulated groundwater release at Building 60, Wright-Patterson Air Force Base. 


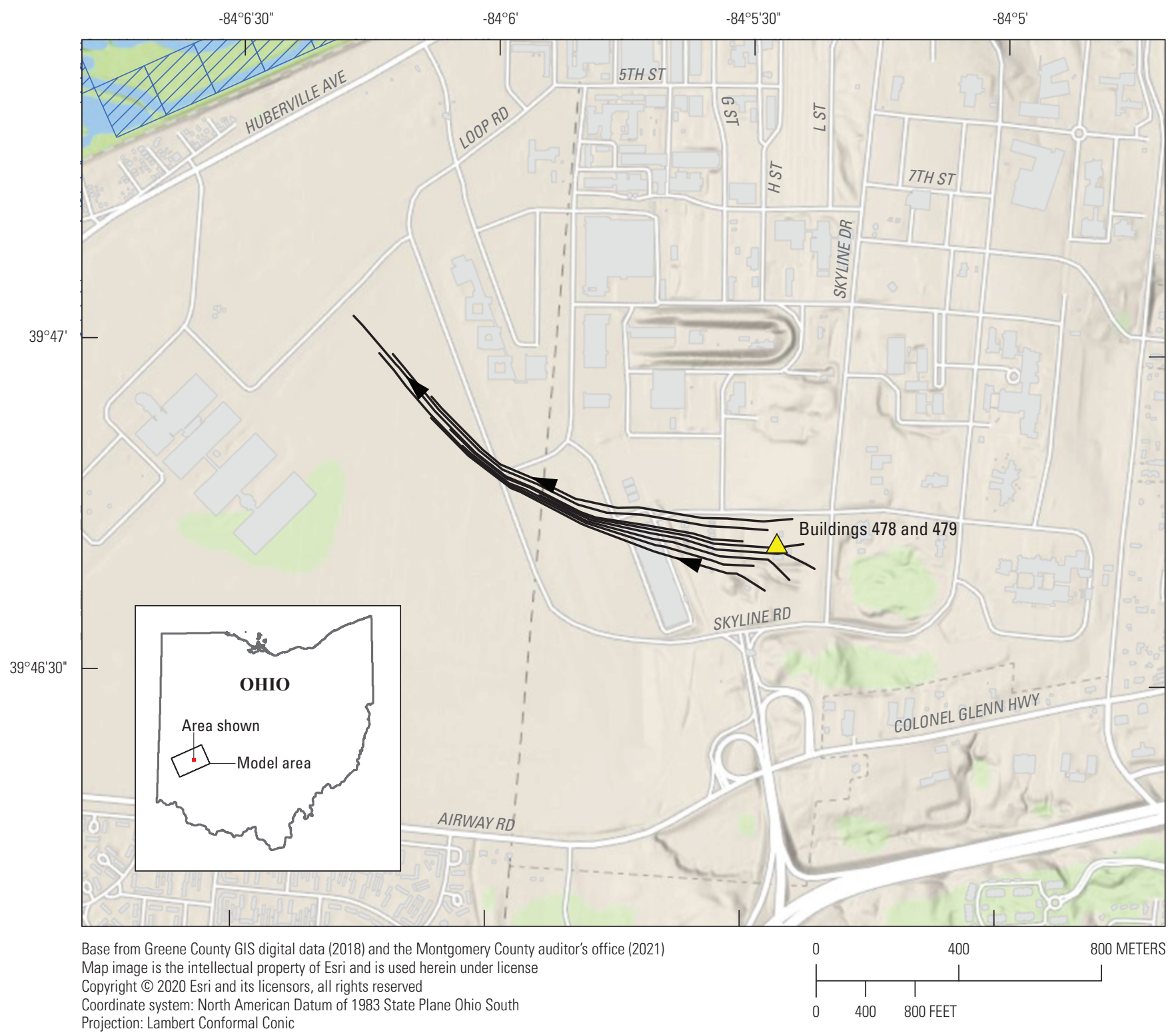

Coordinate system: North American Datum of 1983 State Plane Ohio South

\section{EXPLANATION}

\section{V/A Simulated river cells}

Groundwater flow pathlines

$\triangle \quad$ Simulated release area

Figure 16. Particle pathlines for a simulated groundwater release at Buildings 478/479, Wright-Patterson Air Force Base. 


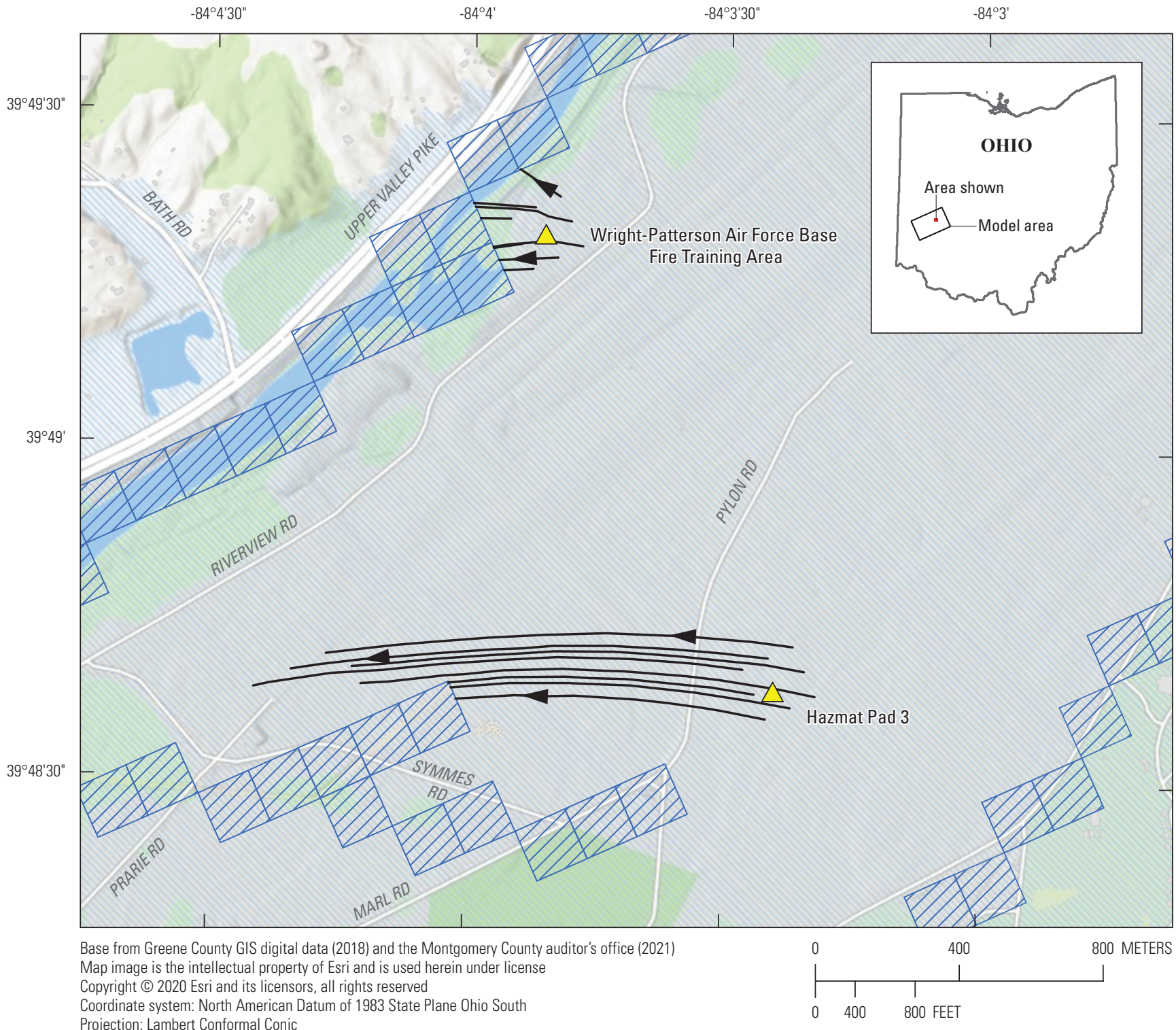

\section{EXPLANATION}

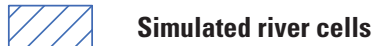

Figure 17. Particle pathlines for a simulated groundwater release at WPAFB Fire Training Area and Hazmat Pad 3, Wright-Patterson Air Force Base. 


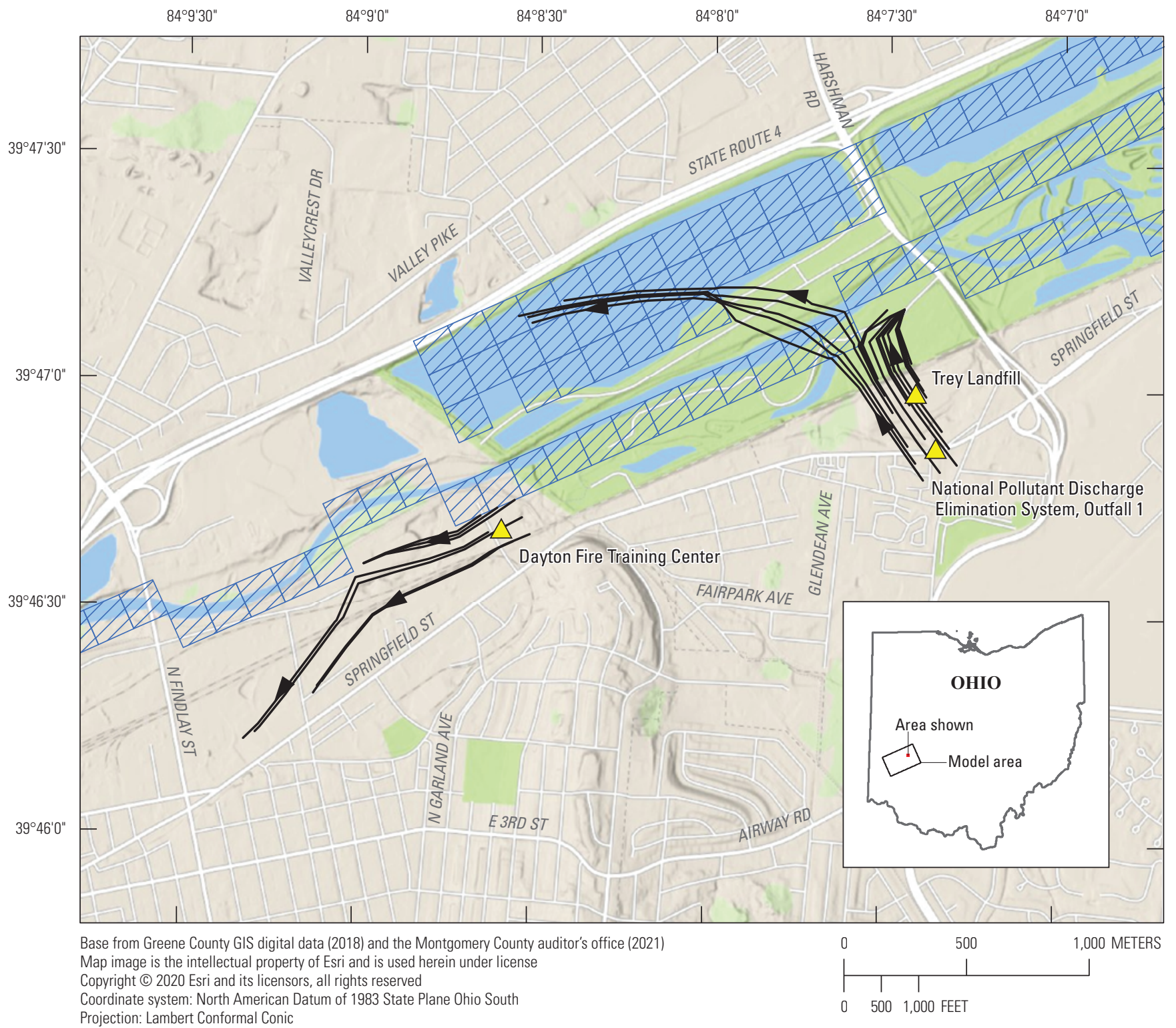

Proordinate systh American Dat

Projection: Lambert Conformal Conic

\section{EXPLANATION}

Simulated river cells

Groundwater flow pathlines
Simulated release areas

Figure 18. Particle pathlines for a simulated groundwater release at Trey Landfill, City of Dayton Fire Training Center, and Outfall 1, Wright-Patterson Air Force Base. 
effective porosity value of 0.2 for all three model layers. Although changes to the effective porosity would not affect the simulated flow system or hydraulic head distribution, effective porosity would change computed travel times from recharge to discharge areas due to the inverse linear relation between groundwater flow velocity and effective porosity.

The effect of small-scale variations in pumping were also not captured in the updated model. Because the steadystate simulation requires a constant pumping rate for each groundwater withdrawal site, average rates had to be calculated in situations where rates would vary during the course of a year (for example, irrigation wells that may only pump for several months of the year, or wells in larger wellfields being cycled on/off to meet demand and maintenance requirements). Some lower capacity wells may not have been included because pumping rates for groundwater withdrawal sites other than Dayton and the Base were calculated from Ohio Department of Natural Resources Significant Water Withdrawal Facility records, which only records withdrawals for sites that are capable of withdrawing more than 100,000 gallons per day.

\section{Summary}

A previously constructed numerical model simulating the regional groundwater flow system in the vicinity of the Wright-Patterson Air Force Base near Dayton, Ohio, was updated to improve the comparison of simulated results to observed data, enhance understanding of the groundwater flow system based on the most recently observed hydrologic conditions and stresses, and improve the usefulness of the model for water-supply planning and protection.

The original model, which simulated conditions from 1997 to 2001, was recalibrated to represent average groundwater flow conditions for October 2018. The steadystate, three-dimensional, three-layer MODFLOW model of the Great Miami buried-valley aquifer encompasses about 241 square miles in Montgomery, Greene, and Clark Counties. As described by Dumouchelle (1998), the Great Miami buried-valley aquifer consists of glacial sands and gravels in a buried valley. The shale bedrock in the area is considered impermeable, but the glacial deposits can yield as much as 2,000 gallons per minute to wells. Because groundwater is the primary source of drinking water in the heavily populated study area, groundwater pumping from the buriedvalley aquifer represents the largest time-varying stress in the groundwater flow model. The model simulated 228 pumped wells. Hydraulic conductivities in the model ranged from less than 1 foot per day to 450 feet per day. Simulated recharge rates ranged from 6 inches per year to 12.2 inches per year.
Boundary conditions and aquifer properties were unchanged from the previous model. Model grid spacing and orientation also were not modified from the previous model.

Parameter estimation software (PEST ++ ) was used to optimize model input parameters by matching simulated water levels to measured water levels in 124 observation wells. Streamflow gain/loss measurements from select reaches of the Mad River and its tributaries were compared with simulated gain/loss but were not used for calibration. Calibration parameters included horizontal hydraulic conductivity, vertical hydraulic conductivity, riverbed conductance, and recharge. Performance of the updated model is similar to previous studies. Eighty-five percent of simulated hydraulic heads were within 10 feet of the measured hydraulic heads, but streamflow gain/loss is not simulated well by the updated model.

\section{References Cited}

Cunningham, W.L., Sheets, R.A., and Schalk, C.W., 1994, Evaluation of ground-water flow by particle tracking, Wright-Patterson Air Force Base, Ohio: U.S. Geological Survey Water-Resources Investigations Report 94-4243, 11 p. [Also available at https://doi.org/10.3133/wri944243].

CH2M Hill, Inc., 1986, Miami well field study, environmental protection program plan report: Prepared for the city of Dayton, v. 1 [variously paged].

CH2M Hill, Inc., 1989, Phase II, Miami north well field study environmental testing and development program: Prepared for the city of Dayton [variously paged].

CH2M Hill, Inc., 2011, Final Report, Source Water Protection Delineation Model Update: Prepared for the city of Dayton, Ohio, 38 p.

Dames \& Moore, Eagon \& Associates, and Clement International Corporation, 1992, Remedial investigation report, Powell Road Landfill: Prepared for SCA Services of Ohio, Inc. [variously paged].

Dieter, C.A., Linsey, K.S., Caldwell, R.R., Harris, M.A., Ivahnenko, T.I., Lovelace, J.K., Maupin, M.A., and Barber, N.L., 2018, Estimated use of water in the United States County-Level data for 2015 (ver. 2.0, June 2018): U.S. Geological Survey data release, https://doi.org/10.5066/F7TB15V5.

Doherty, J., 2010, PEST, model independent parameter estimation-User manual (5th ed., with slight additions): Brisbane Australia, Watermark Numerical Computing, $336 \mathrm{p}$. 
Dumouchelle, D.H., Schalk, C.W., Rowe, G.L., and de Roche, J.T., 1993, Hydrogeology, simulated groundwater flow, and ground-water quality, Wright-Patterson Air Force Base, Ohio: U.S. Geological Survey Water Resources Investigation Report 93-4047, 160 p. [Also available at https://doi.org/10.3133/wri934047].

Dumouchelle, D.H., 1998, Simulation of ground-water flow, Dayton area, southwestern Ohio: U.S. Geological Survey Water-Resources Investigations Report 98-4048, 57 p. [Also available at https://doi.org/10.3133/wri984048].

Fenneman, N.M., 1938, Physiography of Eastern United States: New York, McGraw-Hill, p. 449-536.

Geraghty \& Miller, Incorporated, 1987, Mad River well field assessment: Prepared for the city of Dayton [variously paged].

Harbaugh, A.W., Banta, E.R., Hill, M.C., and McDonald, M.G., 2000, MODFLOW-2000, the U.S. Geological Survey modular ground-water model-User guide to modularization concepts and the ground-water flow process: U.S. Geological Survey Open-File Report 00-92, 121 p. [Also available at https://doi.org/10.3133/ofr200092].

Hill, M.C., Banta, E.R., Harbaugh, A.W., and Anderman, E.R., 2000, MODFLOW-2000, the U.S. Geological Survey modular ground-water model-User guide to the observation, sensitivity and parameter-estimation processes and three post-processing programs: U.S. Geological Survey Open-File Report 00-184, 210 p. [Also available at https://doi.org/10.3133/ofr00184].

Langevin, C.D., Hughes, J.D., Banta, E.R., Niswonger, R.G., Panday, S., and Provost, A.M., 2017, Documentation for the MODFLOW 6 Groundwater Flow Model: U.S. Geological Survey Techniques and Methods, book 6, chap. A55, 197 p. [Also available at https://doi.org/10.3133/tm6A55].

National Oceanic and Atmospheric Administration, 2021, NGS Coordinate and Transformation Tool (NCAT): National Oceanic and Atmospheric Administration web page, accessed September 24, 2021, at https://www.ngs .noaa.gov/NCAT/.

Ohio General Assembly, 2019, Registering facilities capable of withdrawing more than 100,000 gallons a day - rules for ground water stress areas: Ohio General Assembly House Bill 166, 2 p., accessed May 10, 2020, at https://codes .ohio.gov/assets/laws/revised-code/authenticated/15/1521/ 1521.16/10-17-2019/1521.16-10-17-2019.pdf.

Panterra Associates, 1988, A groundwater source protection program, New Carlisle, Ohio-System evaluation study: Prepared for New Carlisle and Clark County, 42 p., appendixes.
Pollock, D.W., 2016, User guide for MODPATH Version 7-A particle-tracking model for MODFLOW: U.S. Geological Survey Open-File Report 2016-1086, 35 p. [Also available at https://doi.org/10.3133/ofr20161086].

Riddle, A.D., 2021, MODFLOW 6 and MODPATH 7 model data sets used for the update of the groundwater flow model for the Great Miami buried-valley aquifer in the vicinity of Wright-Patterson Air Force Base near Dayton, Ohio: U.S. Geological Survey data release, https://doi.org/ 10.5066/P9FN1JK4.

Schalk, C.W., 1992, Ground-water levels and flow in the vicinity of Wright-Patterson Air Force Base, Ohio, OctoberDecember, 1987: U.S. Geological Survey Water-Resources Investigations Report 92-4022, 1 sheet, scale 1:46,980 [Also available at https://doi.org/10.3133/wri924022].

Sheets, R.A., 1994, Contributing recharge areas of watersupply wells at Wright-Patterson Air Force Base, Ohio: U.S. Geological Survey Water Resources Investigations Report 94-4231, 35 p. [Also available at https://pubs .usgs.gov/wri/1994/4231/report.pdf].

Sheets, R.A., 2007, Hydrogeologic setting and ground-water flow simulations of the Great Miami Basin Regional Study Area, Ohio, in Paschke, S.S., ed., Hydrogeologic settings and ground-water flow simulations for regional studies of the transport of anthropogenic and natural contaminants to public-supply wells - studies begun in 2001-Reston, Va: U.S. Geological Survey Professional Paper 1737-A, p. 7-1-7-24. [Also available at https://doi.org/10.3133/ pp1737A].

U.S. Environmental Protection Agency, 1993, Designated sole source aquifers nationally. Office of Ground Water Protection, $12 \mathrm{p}$.

Walton, W.C., and Scudder, G.D., 1960, Ground-water resources of the valley-train deposits in the Fairborn area, Ohio: Ohio Department of Natural Resources, Division of Water Technical Report 3, 57 p.

White, J.T., Hunt, R.J., Fienen, M.N., and Doherty, J.E., 2020, Approaches to highly parameterized inversion: PEST++ Version 5, a software suite for parameter estimation, uncertainty analysis, management optimization and sensitivity analysis: U.S. Geological Survey Techniques and Methods 7C26, $51 \mathrm{p}$. [Also available at https://doi.org/ $10.3133 / \mathrm{tm} 7 \mathrm{C} 26]$.

Yost, W.P., 1995, Data on ground-water levels and groundwater/surface-water relations in the Great Miami River and Little Miami River Valleys, southwestern Ohio: U.S. Geological Survey Open-File Report 95-357, 57 p. [Also available at https://doi.org/10.3133/ofr95357]. 


\section{Appendix 1}

Table 1.1. Source information and water-level data for observation wells used as calibration targets in the parameter estimation process.

Table 1.2. Model pumping rates for Wright-Patterson Air Force Base existing groundwater withdrawal sites.

Table 1.3. Model pumping rates for Wright-Patterson Air Force Base proposed groundwater withdrawal sites. 
Table 1.1. Source information and water-level data for observation wells used as calibration targets in the parameter estimation process. (These data are included with the model archive at https://doi.org/10.5066/P9FN1JK4; Riddle, 2021).

[ID, identification; ft, foot; NGVD 29, National Geodetic Vertical Datum of 1929; NAVD 88, North American Vertical Datum of 1988; WPAFB, Wright-Patterson Air Force Base; USGS, U.S. Geological Survey]

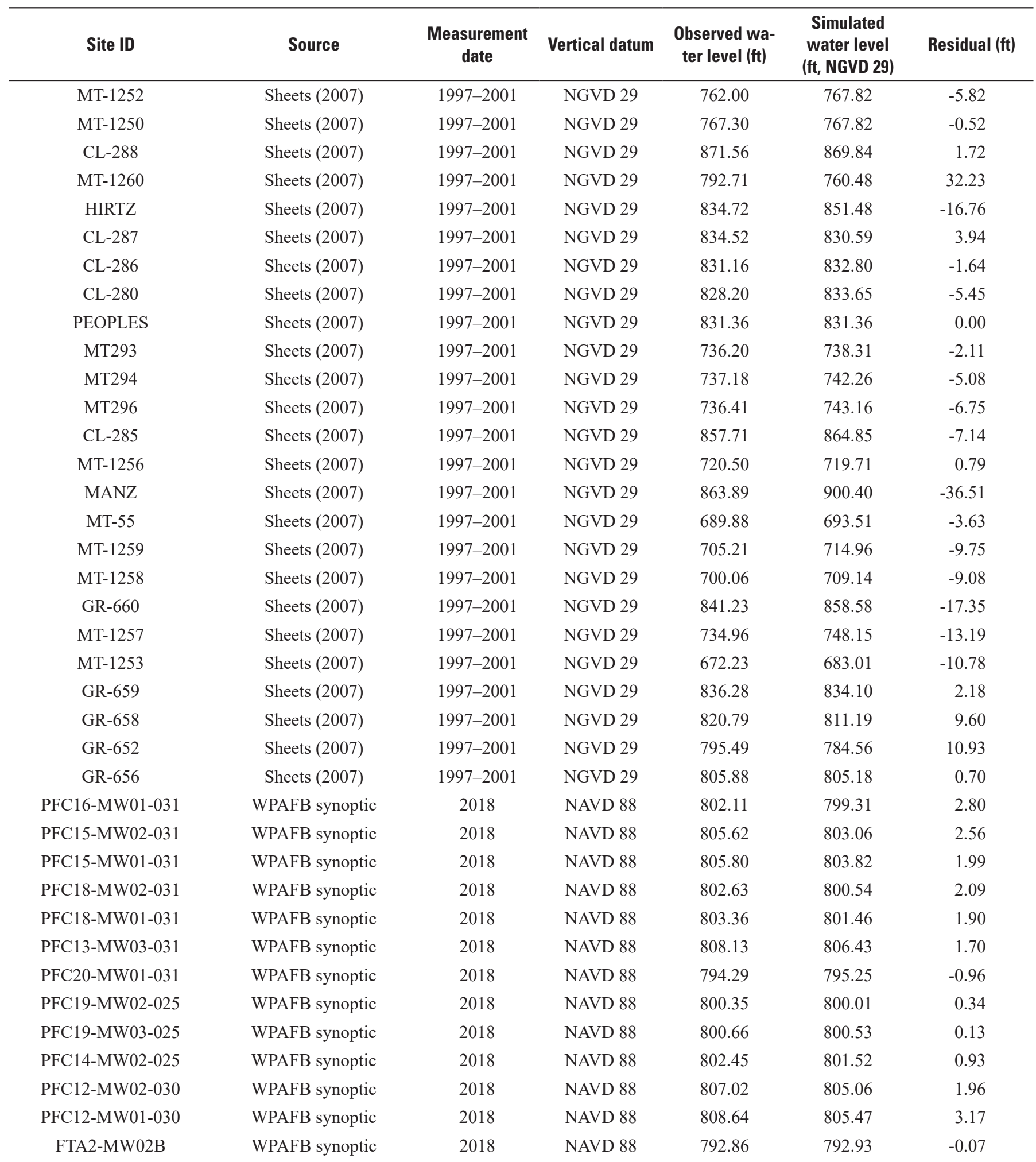


Table 1.1. Source information and water-level data for observation wells used as calibration targets in the parameter estimation process. (These data are included with the model archive at https://doi.org/10.5066/P9FN1JK4; Riddle, 2021).—Continued

[ID, identification; ft, foot; NGVD 29, National Geodetic Vertical Datum of 1929; NAVD 88, North American Vertical Datum of 1988; WPAFB, Wright-Patterson Air Force Base; USGS, U.S. Geological Survey]

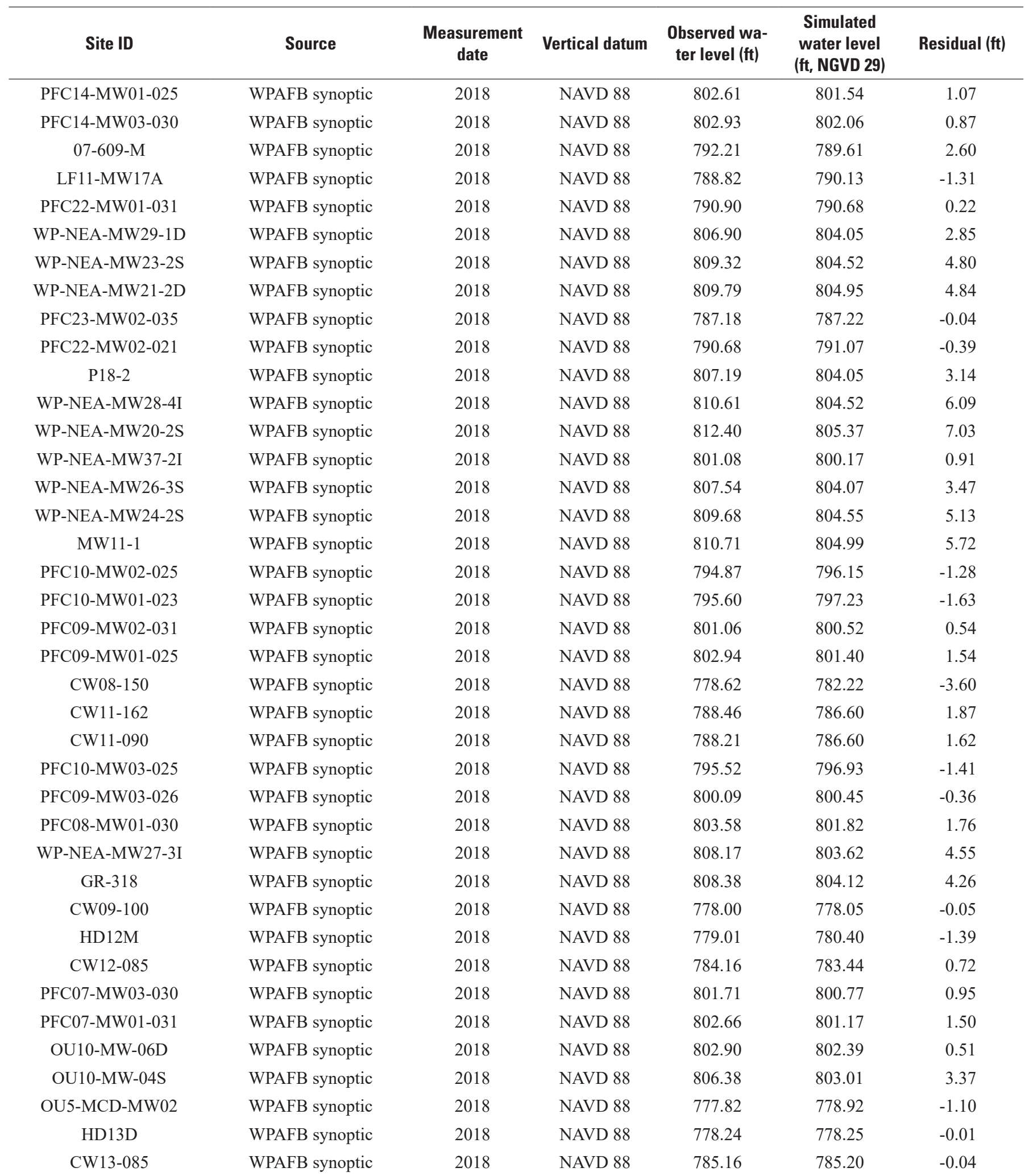


Table 1.1. Source information and water-level data for observation wells used as calibration targets in the parameter estimation process. (These data are included with the model archive at https://doi.org/10.5066/P9FN1JK4; Riddle, 2021).—Continued

[ID, identification; ft, foot; NGVD 29, National Geodetic Vertical Datum of 1929; NAVD 88, North American Vertical Datum of 1988; WPAFB, Wright-Patterson Air Force Base; USGS, U.S. Geological Survey]

\begin{tabular}{|c|c|c|c|c|c|c|}
\hline Site ID & Source & $\begin{array}{l}\text { Measurement } \\
\text { date }\end{array}$ & Vertical datum & $\begin{array}{c}\text { Observed wa- } \\
\text { ter level (ft) }\end{array}$ & $\begin{array}{c}\text { Simulated } \\
\text { water level } \\
\text { (ft, NGVD 29) }\end{array}$ & Residual (ft) \\
\hline PFC11-MW01-025 & WPAFB synoptic & 2018 & NAVD 88 & 795.73 & 796.92 & -1.19 \\
\hline OU10-MW-11D & WPAFB synoptic & 2018 & NAVD 88 & 801.43 & 799.96 & 1.47 \\
\hline OU10-MW-03S & WPAFB synoptic & 2018 & NAVD 88 & 807.21 & 802.37 & 4.84 \\
\hline OU10-MW-02D & WPAFB synoptic & 2018 & NAVD 88 & 807.99 & 803.00 & 5.00 \\
\hline MW133S & WPAFB synoptic & 2018 & NAVD 88 & 778.32 & 779.08 & -0.76 \\
\hline CW04-085 & WPAFB synoptic & 2018 & NAVD 88 & 772.73 & 780.17 & -7.44 \\
\hline 08-022-M & WPAFB synoptic & 2018 & NAVD 88 & 780.40 & 782.41 & -2.01 \\
\hline P3-4 & WPAFB synoptic & 2018 & NAVD 88 & 794.13 & 791.86 & 2.27 \\
\hline PFC06-MW03-026 & WPAFB synoptic & 2018 & NAVD 88 & 800.35 & 800.17 & 0.18 \\
\hline OU10-MW-07DR & WPAFB synoptic & 2018 & NAVD 88 & 802.03 & 801.79 & 0.24 \\
\hline P17-2 & WPAFB synoptic & 2018 & NAVD 88 & 787.12 & 789.01 & -1.89 \\
\hline P3-2 & WPAFB synoptic & 2018 & NAVD 88 & 794.69 & 793.33 & 1.36 \\
\hline GR-333 & WPAFB synoptic & 2018 & NAVD 88 & 800.20 & 799.92 & 0.28 \\
\hline CW3-77 & WPAFB synoptic & 2018 & NAVD 88 & 770.55 & 770.37 & 0.18 \\
\hline PFC04-MW01-030 & WPAFB synoptic & 2018 & NAVD 88 & 804.36 & 800.74 & 3.63 \\
\hline MT-247 & WPAFB synoptic & 2018 & NAVD 88 & 763.24 & 766.44 & -3.20 \\
\hline OU4-MW-02C & WPAFB synoptic & 2018 & NAVD 88 & 796.95 & 798.75 & -1.80 \\
\hline 01-DM-102S-M & WPAFB synoptic & 2018 & NAVD 88 & 819.40 & 811.51 & 7.89 \\
\hline GR-330 & WPAFB synoptic & 2018 & NAVD 88 & 809.98 & 801.10 & 8.89 \\
\hline 01-DM-101D-M & WPAFB synoptic & 2018 & NAVD 88 & 828.26 & 838.31 & -10.05 \\
\hline PFC24-MW01-031 & WPAFB synoptic & 2018 & NAVD 88 & 808.26 & 801.58 & 6.68 \\
\hline EFD09-M575 & WPAFB synoptic & 2018 & NAVD 88 & 878.81 & 857.48 & 21.33 \\
\hline EFD04-MW06 & WPAFB synoptic & 2018 & NAVD 88 & 871.06 & 860.74 & 10.32 \\
\hline CL-11 & USGS network & 2018 & NAVD 88 & 847.13 & 843.96 & 3.17 \\
\hline MT-1255 & USGS network & 2019 & NAVD 88 & 751.94 & 739.80 & 12.14 \\
\hline MT-1251 & USGS network & 2019 & NAVD 88 & 785.98 & 777.53 & 8.45 \\
\hline MT-73 & USGS network & 2018 & NAVD 88 & 734.32 & 743.40 & -9.08 \\
\hline CL-10 & USGS network & 2018 & NAVD 88 & 829.32 & 826.13 & 3.19 \\
\hline MT-74 & USGS network & 2018 & NAVD 88 & 735.35 & 722.88 & 12.48 \\
\hline
\end{tabular}


Table 1.1. Source information and water-level data for observation wells used as calibration targets in the parameter estimation process. (These data are included with the model archive at https://doi.org/10.5066/P9FN1JK4; Riddle, 2021).—Continued

[ID, identification; ft, foot; NGVD 29, National Geodetic Vertical Datum of 1929; NAVD 88, North American Vertical Datum of 1988; WPAFB, Wright-Patterson Air Force Base; USGS, U.S. Geological Survey]

\begin{tabular}{ccccccr}
\hline Site ID & Source & $\begin{array}{c}\text { Measurement } \\
\text { date }\end{array}$ & Vertical datum & $\begin{array}{c}\text { Observed wa- } \\
\text { ter level (ft) }\end{array}$ & $\begin{array}{c}\text { Simulated } \\
\text { water level } \\
\text { (ft, NGVD 29) }\end{array}$ & Residual (ft) \\
\hline MT-6 & USGS network & 2018 & NAVD 88 & 701.80 & 723.39 & -21.59 \\
MT-426 & USGS network & 2018 & NAVD 88 & 676.40 & 718.54 & -42.14 \\
MT-3 & USGS network & 2018 & NAVD 88 & 685.63 & 717.77 & -32.14 \\
MT-49 & USGS network & 2018 & NAVD 88 & 693.44 & 694.97 & -1.53 \\
GR-651 & USGS network & 2019 & NAVD 88 & 822.90 & 825.84 & -2.94 \\
GR-650 & USGS network & 2019 & NAVD 88 & 746.45 & 786.02 & -39.57 \\
GR-1 & USGS network & 2018 & NAVD 88 & 811.37 & 802.87 & 8.50 \\
GR-12 & USGS network & 2018 & NAVD 88 & 766.77 & 799.14 & -32.37 \\
\hline
\end{tabular}

Table 1.2. Model pumping rates for Wright-Patterson Air Force Base existing groundwater withdrawal sites. (These data are included with the model archive at https://doi.org/10.5066/P9FN1JK4; Riddle, 2021).

$\left[\mathrm{ft}^{3} / \mathrm{d}\right.$, cubic feet per day]

\begin{tabular}{|c|c|c|c|}
\hline \multirow{2}{*}{ Wellfield } & \multirow{2}{*}{ Site ID } & \multicolumn{2}{|c|}{ Pumping rate $\left(\mathrm{ft}^{3} / \mathrm{d}\right)$} \\
\hline & & Calibration & Groundwater contributing area delineation \\
\hline \multirow{4}{*}{ Area B } & 1 & 69,427 & 17,216 \\
\hline & $2 \mathrm{~A}, 2 \mathrm{~B}$ & 3,019 & 44,960 \\
\hline & 4 & 0 & 125,483 \\
\hline & 5 & 117,293 & 64,926 \\
\hline \multirow{9}{*}{ Area A } & 1 & 13,368 & 16,828 \\
\hline & 2 & 0 & 14,748 \\
\hline & 3 & 22,424 & 29,945 \\
\hline & 7 & 28,461 & 30,803 \\
\hline & 8 & 28,030 & 44,080 \\
\hline & 9 & 63,390 & 61,286 \\
\hline & MGC2/WS-6 & 6,037 & 7,560 \\
\hline & MGC1/WS-D & 10,349 & 10,625 \\
\hline & EW-1 & 97,026 & 116,552 \\
\hline
\end{tabular}


Table 1.3. Model pumping rates for Wright-Patterson Air Force Base proposed groundwater withdrawal sites. (These data are included with the model archive at https://doi.org/10.5066/P9FN1JK4; Riddle, 2021).

$\left[\mathrm{ft}^{3} / \mathrm{d}\right.$, cubic feet per day]

\begin{tabular}{cc}
\hline Site ID & Pumping rate (ft $\mathbf{3} / \mathbf{d})$ \\
\hline SW-1 & 61,286 \\
SW-2 & 61,286 \\
SW-3 & 61,286 \\
SW-4 & 125,483 \\
WPAFB Fire Training Area/SW-5 & 61,286 \\
Hangar 4020/SW-6 & 61,286 \\
Hazmat Pad 3/SW-7 & 61,286 \\
Building 60/SW-8 & 61,286 \\
\hline
\end{tabular}

\section{References Cited}

Riddle, A.D., 2021, MODFLOW 6 and MODPATH 7 model data sets used for the update of the groundwater flow model for the Great Miami buried-valley aquifer in the vicinity of Wright-Patterson Air Force Base near Dayton, Ohio: U.S. Geological Survey data release, https://doi.org/ 10.5066/P9FN1JK4.
Sheets, R.A., 2007, Hydrogeologic setting and ground-water flow simulations of the Great Miami Basin Regional Study Area, Ohio, in Paschke, S.S., ed., Hydrogeologic settings and ground-water flow simulations for regional studies of the transport of anthropogenic and natural contaminants to public-supply wells - studies begun in 2001-Reston, Va: U.S. Geological Survey Professional Paper 1737-A, p. 7-1-7-24. 
For additional information contact:

Director, USGS Ohio-Kentucky-Indiana Water Science Center U.S. Geological Survey

5957 Lakeside Boulevard

Indianapolis, IN 46278

317-290-3333

For additional information, visit:

https://www.usgs.gov/centers/oki-water

Publishing support provided by

the Indianapolis Publishing Service Center 
